Wiktor MARZEC

Uniwersytet Środkowoeuropejski w Budapeszcie

Marzec_Wiktor@phd.ceu.edu

\title{
POLITYKA POJĘĆ
}

\section{IDEOLOGOWIE NARODOWEJ DEMOKRACJI I POJĘCIE POLITYKI U PROGU XX W.}

ABSTRACT The politics of concepts. Polish National Democrats and the concept of politics in early 20th century

The article undertakes a conceptual analysis of the concept of politics in political writings of Polish National Democracy in the turn of 19th and 20th century. I argue, that due democratization and modernization, it was a time of conceptual change and emergence of modern social and political concepts in Polish. Drawing from conceptual history and rhetorical analysis of topoi, used to express the concept of politics, I investigate National Democratic invention in conceptual rendition of politics. The two major kinds of topoi are: temporal (politics as action); and spatial (politics as sphere). An investigation into their mutual relationship assists understanding of a major change in National Democratic political thought and practice in that heated period. The gradual prevalence of spatial conceptualization and accompanying depoliticization of political enemies was an important factor in the process of sliding into authoritarian, antidemocratic and elitist understanding of politics among National Democrats in the forthcoming years.

Słowa kluczowe: Narodowa Demokracja, endecja, polityka, to, co polityczne, historia pojęć, analiza retoryczna, topika

Keywords: National Democracy, endecja, politics, the political, conceptual history, rhetorical analysis, topoi 
$W$ dziejach narodów wypadkami stokroć wazniejszymi od wojen, najsć i rewolucji sa gtębokie przeobrażenia, zachodzace wich myśli politycznej, w wielkich przestankach, stanowiacych wytyczne dalszego ich życia.

Zygmunt Balicki $^{1}$

\section{NOWY CZAS POLITYKI}

Jak odnotował Sheldon Wolin, badając innowacje w myśli politycznej, większość doniostych deklaracji filozofii politycznej zostata poczyniona w czasach kryzysu; to jest wtedy, gdy zjawiska polityczne byty stabiej zintegrowane z formami instytucjonalnymi ${ }^{2}$. Z takim momentem mamy bez wątpienia do czynienia w polskich debatach ideowych trwających około od roku 1880 do okresu następującego bezpośrednio po rewolucji 1905-1907. Jest to okres istotnej rekonfiguracji pola politycznego, przynoszącej zarówno demokratyzację (kulminującą w rewolucji), powstanie nowych formacji politycznych i masowych partii, jak i wykształcenie nieobecnych wcześniej opcji ideowych. Wraz ze spadkiem znaczenia pozytywizmu jako dominującej formacji ideowej spór konserwatystów z pozytywistami, który ogniskował uwagę opinii publicznej w Królestwie Polskim w latach 70. XIX w. ${ }^{3}$, ustąpił miejsca polemikom wśród wchodzącego na scenę pokolenia antysystemowych radykałów ${ }^{4}$. To z niego potem wykształcą się nowe na polskim gruncie prądy - nacjonalistyczny i socjalistyczny. Te będą już w pełni wytworami nowoczesnej masowej sfery politycznej.

Zmiana ta miała też swoje korelaty w zakresie językowego ujmowania świata. Okres ten to wytanianie się nowoczesności w jej aspektach jezzykowych ${ }^{5}$, nastanie pojęciowego „nowego czasu”. Mowa tu o procesie analogicznym, choć różnym, do tego, który w odniesieniu do niemieckiego obszaru językowego opisał Reinhart Koselleck, a francuskiego Rolf Reichardt ${ }^{6}$. Koselleck określił ów czas mianem Sattelzeit - czas przejścia. Jak pisze tłumacz pracy Kosellecka, Wojciech Kunicki, ten obrazowy zwrot oznacza epokę wczesnej nowożytności, zatem lata 1750-1800, kiedy to wyksztatcity się wszystkie ważniejsze pojęcia, będace naszymi pojęciami. Obraz sugeruje z jednej strony ruch, z drugiej swoiste osadzenie się w tych kategoriach pojęciowych, które sa naszymi kategoriami ${ }^{7}$.

Niepodlegtość wewnętrzna, [w:] Z. Balicki, Parlamentaryzm. Wybór pism, Kraków 2008, s. 441.

2 S.S. Wolin, Politics and Vision. Continuity and Innovation in Western Political Thought, Princeton 2004, s. 9.

3 A. Jaszczuk, Spór pozytywistów z konserwatystami o przysztość Polski 1870-1903, Warszawa 1986.

4 Prace na jego temat, pisane z wyraźnych, istotnych w kontekście ich publikacji perspektyw, to: B. Cywiński, Rodowody niepokornych, Warszawa 2010; A. Mencwel, Etos lewicy. Esej o narodzinach kulturalizmu polskiego, Warszawa 2009.

5 R. Koselleck, Semantyka historyczna, przeł. W. Kunicki, Poznań 2012, s. 34.

6 Handbuch politisch-sozialer Grundbegriffe in Frankreich 1680-1820, red. R. Reinchardt, München 1985.

7 Por. R. Koselleck, Einleitung, [w:] Geschichtliche Grundbegriffe, t. 1, Stuttgart 1972; Stownik, [w:] R. Koselleck, Semantyka historyczna, s. 563. 
Jednocześnie zmiana taka to okres intensywnego przekształcenia pojęcia "polityka” i zmiany podstawowej topiki, z pomocą której było ono metaforyzowane, wyrażane i opisywane ${ }^{8}$.

Przekształcenia w zakresie rozumienia pojęcia polityki - z jednej strony jako dziedziny działalności ludzkiej, a z drugiej jako specyficznego działania - były badane przez Kariego Palonena9. Przedmiotem uwagi fińskiego badacza jest pojęcie polityki czy też polityka jako pojęcie. Kroczy on szlakiem wytyczonym przez Kosellecka w jego projekcie Begriffsgeschichte. Pojęcie zatem rozumie jako słowo skupiające szeroki wachlarz społecznych i politycznych znaczeń. Mieści ich tak wiele, jeśli nie jest on wręcz nieograniczony, że pojęcie jako koncentracja znaczeń jest zawsze polisemantyczne i dlatego staje się przedmiotem mniej lub bardziej jawnej polemiki, rywalizacji i walki ${ }^{10}$. Pojęcie staje się przestrzenią oznaczania, inskrypcji dokonywanych przez różnych społecznych aktorów, jest interpretowane i reinterpretowane na różne sposoby, stając się polem bitwy.

Palonen w tym świetle rozważa, jak „polityka” jest opisywana i rozumiana, jakie metafory i zakresy topiczne wykorzystywane są do językowego wyrażenia tej sfery. Podstawowa linia podziału organizująca odnośne wypowiedzi dotyczy tego, czy polityka jest wyrażana w kategoriach przestrzennych czy czasowych - a zatem, odpowiednio, jako pewna sfera czy raczej jako działanie. Palonen bada historię temporalizacji polityki, przejście od ujmowania jej jako pewnej dziedziny wiedzy czy dyscypliny ${ }^{11}$ do rozumienia jej jako praktyki społecznej - wyrażanej w nowoczesności jako określona sfera (konceptualizacja przestrzenna) bądź też aktywność, działanie (konceptualizacja czasowa). Owe dwie konceptualizacje stanowią niejako dwa, polemiczne względem siebie, nurty rozumienia nowoczesnej polityki, które w poszczególnych dyskursach na temat polityki nieustannie się przeplatają (wystarczy pomyśleć o sformułowaniu takim jak „sfera działania”) ${ }^{12}$. Autor ten rozpatruje zmianę pojęciową, korzystając z tradycji retorycznej - poprzez badanie procesu formowania się określonych repertuarów topoi, poszukiwanie loci communes, sposobów opisu metaforycznego służących do konceptualizacji polityki ${ }^{13}$. Jak zatem rysuje się ogólny obraz czasu przejścia w kontekście polskiego języka społeczno-politycznego?

8 Zob. np. Semantiken des Politischen. Vom Mittelalter bis ins 20. Jahrhundert, red. U. Meier, W. Steinmetz, M. Pappenheim, Göttingen 2012; K. Palonen, Politik als Handlungsbegriff. Horizontwandel d. Politikbegriffs in Deutschland 1890-1933, Helsinki 1985; V. Sellin, Politik, [w:] Geschichtliche Grundbegriffe, t. 4, Stuttgart 1974.

9 K. Palonen, The Struggle with Time. A Conceptual History of „Politics” as an Activity, Hamburg 2006.

10 N.A. Andersen, Discursive Analytical Strategies. Understanding Foucault, Koselleck, Laclau, Luhmann, Bristol 2003; J. Ifversen, About Key Concepts and How to Study Them, „Contributions to the History of Concepts" 2011, Vol. 6, nr 1; R. Koselleck, Einleitung.

11 Paradygmatyczny przykład klasycznego ujęcia to oczywiście Arystoteles, Polityka, Warszawa 2004.

12 Zob. także syntetyczne omówienie tych repertuarów w: Semantiken des Politischen..., s. 80-85.

13 K. Palonen, The Struggle with Time..., s. 21. 


\section{POLSKI CZAS PRZEJŚCIA I TOPIKA POLITYKI}

W przypadku języka polskiego rozwój nowoczesnego słownictwa społeczno-politycznego przebiegał w specyficzny sposób ${ }^{14}$. Z jednej strony polska myśl polityczna miała silną własną tradycję o odrębnych liniach rozwojowych, na którą składały się choćby spuścizna szlacheckiego republikanizmu, silna obecność tradycji arystotelesowskiej czy tomistycznej i utrzymujące się odniesienie polityki do transcendentnego porządku i sfery moralności oraz specyficzna „polityczna” koncepcja narodu szlacheckiego ${ }^{15} . \mathrm{Z}$ drugiej strony, w obliczu zatrzymania rozwoju tradycji państwowych i braku modernizacji społecznej, polski język polityczny w XIX w. przyswajał nowoczesne wpływy z zewnątrz, głównie ze słownictwa francuskiego. Wiele pojęć było przyjmowanych w gotowej formie, a nie wykształcanych w bieżącej praktyce instytucjonalnej, takiej jak walka wyborcza czy parlamentaryzm ${ }^{16}$. Powstał z tego oryginalny amalgamat rozwijający się w czasie wedle rytmu innego niż w przypadku pojęć francuskich czy niemieckich ${ }^{17}$. Cechował się swoistym nawarstwieniem asynchroniczności, współistniejącymi warstwami czasu odmiennymi dla zasobów języka, sytuacji społecznej i praktyki politycznej ${ }^{18}$.

Niemal cały „długi wiek XIX” był okresem kształtowania się nowoczesnych pojęć społeczno-politycznych. Proces ten rozpoczął się pewnym ożywieniem myśli

14 Odnośnie do tego procesu trudno w ogóle mówić o jakiejś „typowej” ścieżce - w przypadku każdego języka wyglądał on nieco inaczej ze względu na inne trajektorie rozwoju społecznego, politycznego i państwowego. Do pewnego stopnia czołowe podejścia w badaniu nowożytnej i nowoczesnej polityki zagnieżdżone są w konkretnym doświadczeniu historycznym, specyfice źródłowej etc. Dotyczy to np. różnic między przypadkiem niemieckim i tradycją badań Begriffsgeschichte a historią języków politycznych w Anglii i tzw. szkołą Cambridge. Jeszcze inne uwarunkowania dotyczą Europy Wschodniej. Zob. B. Trenscnyi, Conceptual History and Political Languages. On the Central-European Adaptation of the Contextualist-Conceptualist Methodologies of Intellectual History, [w:] Prague Perspectives. Studies in Central and Eastern Europe, red. P. Roubal, V. Veber, Prague 2004.

15 Zob. odpowiednio na temat politycznej tradycji szlachty: E. Opaliński, Kultura polityczna szlachty polskiej w latach 1587-1652. System parlamentarny a spoteczeństwo obywatelskie, Warszawa 1995; J. Tazbir, Kultura szlachecka w Polsce. Rozkwit, upadek, relikty, Warszawa 1978. Na temat utrzymującej się długo w Polsce „klasycznej koncepcji racji stanu” pisze A. Rzegocki, Racja stanu a polska tradycja myślenia o polityce, Kraków 2008. O koncepcji narodu zob. A. Walicki, Idea narodu w polskiej myśli oświeceniowej, Warszawa 2000.

16 Waga praktyki wyborczej czy parlamentarnej dla zmiany topiki polityki omówiona jest w: K. Palonen, The Struggle with Time..., s. 74.

17 F. Pepłowski komentuje to w ten sposób: od końca XVIII w. zachodzi bardzo szybki proces tworzenia się stownictwa i frazeologii publicystycznej. [...] Stownictwo i frazeologia tego okresu nie stanowia jakiegoś statego, zamkniętego systemu terminów i jednostek frazeologicznych; obserwujemy tu ustawiczny proces ksztattowania się i rozwoju zjawisk nowych przy równoczesnym wypieraniu starych. F. Pepłowski, Stownictwo i frazeologia polskiej publicystyki okresu Oświecenia i romantyzmu, Warszawa 1961, s. 297.

$18 \mathrm{Na}$ temat warstw czasu w różnych obszarach życia społecznego i wewnątrz samych pojęć zob. m.in. H. Jordheim, Against Periodization. Koselleck's Theory of Multiple Temporalities, „History and Theory” 2012, nr 51; R. Koselleck, Warstwy czasu. Studia z metahistorii, przeł. K. Krzemieniowa, J. Merecki, Warszawa 2012; N. Olsen, History in the Plural. An Introduction to the Work of Reinhart Koselleck, New York 2012. 
państwowo-politycznej pod koniec epoki stanisławowskiej ${ }^{19}$. Debaty emigracyjne ${ }^{20}$, przemyślenie wspólnoty narodowej w dobie popowstaniowej ${ }^{21}$, debaty dotyczące modernizacji ${ }^{22}$ i spory związane $\mathrm{z}$ wypracowaniem języków opisu nowej rzeczywistości ${ }^{23}$ miały także wpływ na zachodzące zmiany. Można by chyba powiedzieć, że Sattelzeit w kontekście polskim rozciąga się przez długi wiek XIX (mniej więcej od publicystyki uczestników Sejmu Wielkiego do debat w przededniu I wojny światowej).

Kluczowy dla zwieńczenia zmiany był okres krystalizacji nowoczesnych języków czy ideologiii ${ }^{24}$, różnicowania się stanowisk i tworzenia masowych ruchów politycznych przypadający na lata pomiędzy około 1880 r. a okresem rozliczeń po rewolucji 1905-1907. Ta ostatnia przypieczętowała podziały i zatwierdziła niejako zaszłe zmiany, będąc jednocześnie skokowym przejściem do świata nowoczesnej, masowej polityki ${ }^{25}$. Następne lata przyniosły okrzepnięcie pojęć stosowanych coraz szerzej wobec nowych zjawisk i ostateczne wykształcenie się języków ideologicznych, szeroko wykorzystywanych podczas kampanii wyborczych do carskiej Dumy ${ }^{26}$.

To ogólne rozpoznanie znajduje potwierdzenie w podstawowych słownikach języka polskiego z tego okresu ${ }^{27}$. Ich lektura uwidacznia wyraźnie, jak duża była skala zmian. Podstawowe pojęcia społeczno-polityczne w słownikach sprzed wspomnianej intensyfikacji zmian jako słowa są obecne, ale niosą ze sobą wciąż przednowoczesne, zupełnie inne od dzisiejszych, czasem niemal niezrozumiałe czy nieuchwytne dla współcze-

19 A. Walicki, Idea narodu...

20 Zob. m.in. S. Kalembka, Wielka emigracja 1831-1863, Toruń 2003; F. Pepłowski, Stownictwo i frazeo$\operatorname{logia} \ldots$

$21 \quad$ T. Kizwalter, O nowoczesności narodu. Przypadek Polski, Warszawa 1999.

22 Tenże, „Nowatorstwo i rutyny”. Spoteczeństwo Królestwa Polskiego wobec procesów modernizacji, 1840-1863, Warszawa 1991.

23 A. Jaszczuk, Spór pozytywistów z konserwatystami...

24 Rozumiem je tu w sposób zaproponowany przez M. Freedena, jako zestawy stosunkowo ustabilizowanych względem siebie i „zdekontestowanych” pojęć, zob. M. Freeden, Ideologies and Political Theory. A Conceptual Approach, Oxford-New York 1998; tenże, Ideology and Conceptual History, [w:] Political Concepts and Time. New Approaches to Conceptual History, red. J.F. Sebastián, Santander 2011.

25 R. Blobaum, Rewolucja. Russian Poland, 1904-1907, Ithaca 1995; Rewolucja 1905. Przewodnik, red. W. Marzec, K. Piskała, Warszawa 2013; Spoteczeństwo i polityka. Dorastanie do demokracji. Kultura polityczna w Królestwie Polskim na początku XX wieku, red. A. Żarnowska, S. Wolsza, Warszawa 1993.

26 R. Blobaum, The Politics of Antisemitism in Fin-de-Siècle Warsaw, „The Journal of Modern History” 2001, Vol. 73, nr 2; Spoteczeństwo i polityka...

27 Słowniki wykazują się pewnego rodzaju inercją i nowe znaczenia słów kanonizowane są w nich z pewnym opóźnieniem wobec żywego języka publicystyki politycznej. Dlatego opisane tu zmiany w niektórych wypadkach w tekstach publicystycznych można odnotować nieco wcześniej, czasem już pod koniec XVIII w. Kompendium wiedzy na ten temat stanowi F. Pepłowski, Stownictwo i frazeologia... Podsumowując obszerne badania nad słownictwem i frazeologią w publicystyce politycznej, autor odnotowuje, iż: od końca XVIII w. zachodzi bardzo szybki proces tworzenia się stownictwa i frazeologii publicystycznej. [...] Stownictwo i frazeologia tego okresu nie stanowia jakiegośstatego, zamkniętego systemu terminów i jednostek frazeologicznych; obserwujemy tu ustawiczny proces ksztattowania się i rozwoju zjawisk nowych przy równoczesnym wypieraniu starych. Tamże, s. 297. 
snego czytelnika treści. Tymczasem słowniki z początku XX w. prezentują już bogate w znaczenia pojęcia społeczno-polityczne, umożliwiające opisanie świata nowoczesnej polityki, których konotacje pozostały niemal niezmienione do dziś (co potwierdzają słowniki zarówno z okresu powojennego, jak i dzisiejsze, będące często bardzo zbieżne w podawanych zestawach definicji). Pojęcia winny być rozpatrywane również jako zmienne w czasie, przede wszystkim jednak jako elementy w relacyjnych, synchronicznych układach semantycznych ${ }^{28}$. Pojęcie polityki jest o tyle szczególne, że dotyka pewnego metapoziomu rozumienia praktyki politycznej w danym dyskursie ideologicznym, wyraża pewien styl myślenia politycznego ${ }^{29}$ i podstawowe sposoby, zawsze metaforycznego, ujęcia własnej działalności ${ }^{30}$.

Pojęcie „polityka” 31 było opisywane zupełnie inaczej na początku i na końcu omawianego okresu. Oczywiście istotą pojęcia jest jego wieloznaczność, interpretowalność i kontestowalnośćc 32 . Mają one jednak pewne granice i w danym kontekście językowym oraz w danym czasie pojęcia zachowują pewien zasób treści wspólnych. Renomowane i opiniotwórcze w okresie publikacji słowniki są pewnym zapisem szeroko przyjmowanej „dekontestacji” określonego pojęcia ${ }^{33} \mathrm{w}$ danym obiegu językowym, zaświadczają o pewnym pojęciowym uzusie ${ }^{34}$.

Przedmiotem przedstawionej poniżej szkicowej analizy wstępnej były dwa podstawowe słowniki języka polskiego wydane w tym okresie: „wydanie drugie poprawione i pomnożone" tzw. Stownika Lindego z $1858^{35}$ r. oraz tzw. Stownik warszawski, wydawany w latach 1901-1927 (podstawowe tomy wychodzily w latach 1907-1914) ${ }^{36}$. Porównawcza lektura hasła „polityka”, kolacjonująca zaproponowane w obu słownikach znaczenia w duchu badania nad historią pojęcia „polityka” zaproponowanego przez Palonena ${ }^{37}$, dostarcza interesujących obserwacji. Dzisiejsze słowniki wskazują na dwa

28 W tym względzie Freeden jest w zasadzie zgodny z Koselleckiem, z tym że w większym stopniu kładzie nacisk na ów strukturalistycznie rozumiany synchroniczny wymiar systemowy. Por. M. Freeden, Ideologies and Political Theory..., s. 48; M. Widzicka, Semantyka historyczna w ujęciu Reinharta Kosellecka. Zarys problematyki, „Historyka” 2010, t. 40, nr 10.

M. Freeden, The Political Theory of Political Thinking. The Anatomy of a Practice, Oxford 2013.

K. Palonen, The Struggle with Time...

polskiej praktyce logicznej i ortograficznej użycie wyrazu w cudzysłowie oznacza jego supozycję materialną. W tym tekście, gdy używam wyrazu „polityka” w cudzysłowie, mam na myśli supozycję materialną lokucyjną, a zatem sam wyraz „polityka” określający swój desygnat. Dodatkowo trzeba pamiętać, że mowa tu o określeniu wieloznacznego, interpretowalnego i kontestowalnego pojęcia, którego regionalna historia w danym kontekście i czasie jest przedmiotem mojego zainteresowania. A zatem ujęcie w cudzysłów odnosi bardziej do samego pojęcia „polityka”, które de facto na gruncie językoznawczym jest już desygnatem samej nazwy.

R. Koselleck, Semantyka historyczna, s. 42.

Zazwyczaj dzieje się to z pewny opóźnieniem, zważywszy na cechującą duże przedsięwzięcia wydawnicze inercję i pewien konserwatyzm.

36 A. Kryński, W. Niedźwiedzki, Stownik jezyka polskiego, Warszawa 1901.

37 K. Palonen, Politik als Handlungsbegriff..., s. 27-31; tenże, The Struggle with Time... 
wymiary: (1) polityka jako dziedzina czy zakres działalności - a więc ujęcie polityki w topice przestrzennej - dziatalność wtadz państwowych, rządu, dotyczaca spraw wewnętrznych państwa i jego stosunków z innymi krajami; (2) działanie - konceptualizacja czasowa - dziatalność [...] uwarunkowana celami i interesami ${ }^{38}$. Stownik Lindego natomiast ogranicza się do definiowania polityki jako dyscypliny, tak jak czyniło to klasyczne ujęcie greckie i cały szereg przednowoczesnych i wczesnonowoczesnych autorów.

Polityka zatem to nauka jak Rzeczpospolita rzadzić $i$ zachować wcale [tzn. w całości - przyp. W.M.] [...], nauka poznawania spraw i potrzeb państw; abo roztropnośćpodająca rzadzacym do wykonania zamystów przedsięwziętych ${ }^{39}$. W przednowoczesnym ujęciu polityka to dyscyplina wiedzy i sprawności państwowej, nie dotyczy zamysłów, a jedynie ich realizacji, doboru środków, jest zatem dyscypliną niemal techniczną. Porzucenie jeszcze starszego rozumienia Arystotelesowskiego, gdzie istotny był horyzont normatywny „dobrego życia” czy realizacji ludzkiej natury, dokonało się już wcześniej $^{40}$. Wydaje się, że zmiana pojęciowa dotycząca pojęcia polityki przebiegała podobnie w różnych językach europejskiej nowoczesności. Badania Palonena wskazują bowiem na analogiczne przejście (od polityki jako dyscypliny do rywalizujących ze sobą konceptualizacji przestrzennej i czasowej) w kontekście angielskim, niemieckim i francuskim. W języku polskim też widać takie przejście i zachodzi ono dosyć szybko, Stownik warszawski bowiem (którego tom z literą "p" wydano w 1907 r.) podaje już definicję zbliżoną do współczesnej. Polityka to sztuka rządzenia państwem, utrzymania $i$ wyzyskiwania stosunków z obcemi państwami, nauka poznawania spraw i potrzeb państw, ale i zasada, system, taktyka, plan postępowania osób rządzacych w kraju ${ }^{41}$. Nie ma tu zatem wyraźnej topiki przestrzennej, ale widać znakomicie, jak starsze znaczenie (słowniki cechują się sporą inercją, opracowanie nowego wydawnictwa to duże przedsięwzięcie i przykłady zaczerpnięte są ze starszych, cenionych wydań) jest uzupełnione konceptualizacją czasową odnoszącą politykę do działania w obliczu danych celów i okoliczności ${ }^{42}$. Przeprowadzona w ramach innego projektu badawczego analiza odezw partii politycznych z okresu rewolucji 1905-1907 potwierdza te rozpoznania - termin polityka jest tam używany wyłącznie w znaczeniu ukierunkowanego działa-

38 Przykłady zaczerpnięte z: Praktyczny stownik wspótczesnej polszczyzny, red. H. Zgółkowa, Poznań 1994.

39 S.B. Linde, Stownik..., t. 4, s. 306. Cały czas bardzo ważne (podawane jako drugie) jest też rozumienie związane z (nie zawsze cenioną) ogładą: dworność, dworska sztuczność, polor.

40 W przypadku języka niemieckiego zob. K. Palonen, Politik als Handlungsbegriff...; V. Sellin, Politik. Wedle A. Rzegockiego horyzont normatywny w polskim rozumieniu „racji stanu”, a zatem i polityki, utrzymał się znacznie dłużej, praktycznie do dziś. Co ciekawe, nie rejestrują tego definicje słownikowe samego terminu „polityka”.

$41 \quad$ A. Kryński, W. Niedźwiedzki, Stownik...

42 Oczywiście polskie pisarstwo polityczne operowało dość rozwiniętą frazeologią polityczną i wśród reformatorów okresu Księstwa Warszawskiego pokroju Staszica czy Kołłątaja pojawiają się nowoczesne konceptualizacje choćby pojęcia narodu. Wydaje się jednak, że pojęcie polityki nie było przedmiotem uwagi, choć ówcześni autorzy używają form pochodnych, przeważnie przymiotnika polityczny, określającego charakterystykę jakiejś dziedziny wiedzy czy postępowania. Zarówno dla romantyków, jak i pozytywistów polityczność zeszła na plan dalszy. Zob. M. Janowski, Polska myśl liberalna do 1918 roku, Kraków-Warszawa 1998; A. Walicki, Idea narodu... 
nia określonego podmiotu (polityka rządu, nasza polityka, polityka pijawek carskich, polityka socjalistyczna $)^{43}$.

Przykłady te pokazują, jaka była skala zmiany pojęciowej na przestrzeni kilkudziesięciu lat. Zmiana taka nie dokonuje się sama. W przypadku podstawowych pojęć społeczno-politycznych jest ona wypadkową różnych rywalizujących ze sobą języków politycznych funkcjonujących w sferze publicznej czy na danym polu debaty. Te z kolei współkształtowane są przez wpływowych mówców czy pisarzy politycznych, których można by nazwać innowatorami pojęciowymi ${ }^{44}$. Zmiana topoi, za pomocą których metaforyzowane jest dane pojęcie, dokonuje się w wypowiedziach owych ideologów-innowatorów, którzy proponowali nowe rozumienia i zastosowania pojęć. Owi filozofowie, pisarze i politycy nie tyle dokonują innowacji leksykalnej, która z czasem staje się normą, chodzi raczej o konceptualizacje nowych zjawisk społeczno-politycznych poprzez nowe pojęcia (niekoniecznie zmienia się sam znak językowy, ale jego zakres odniesień czy znaczone). Często dokonują oni takich modyfikacji świadomie, stając się politykami pojęć $c^{45}$.

\section{NARODOWI DEMOKRACI JAKO INNOWATORZY POJĘCIOWI}

W polskim kontekście językowym rolę innowatorów pojęciowych, a i po trosze polityków pojęć odegrali ideologowie Narodowej Demokracji, szczególnie w okresie kształtowania się podstawowych zrębów ideologii endeckiej (w latach ok. 1896-1904) ${ }^{46}$, która później była z różną konsekwencją aplikowana i dostosowywana do biegu wypadków (rewolucja 1905, kolejne wybory do Dumy itd.). Na skutek określonych koniunktur historycznych dyskurs polityczny endecji stał się niezwykle wpływowy dla całościowo ujętej polskojęzycznej sfery publicznej ${ }^{47}$. Nie tylko przez lata był ważnym

43 Dane uzyskane poprzez zestawienie występowania kodów związanych z pojęciem „polityka” wykonane z wykorzystaniem oprogramowania QDA Miner/WordStat. Głównym korpusem źródłowym był zbiór ulotek politycznych z lat 1904-1907 (uzupełniony materiałami kontekstowymi datowanymi od ok. 1900 do 1912 r.). Zawiera on materiały agitacyjne trzech głównych środowisk politycznych publikujących materiały w języku polskim (NZR/ND, SDKPIL i PPS - potem PPS-Lewica i PPS-FR). Więcej na temat tego badania zob. W. Marzec, Rebelia i reakcja. Rewolucja 1905 roku i plebejskie doświadczenie polityczne, Kraków-Łódź 2016.

44 Nie zawsze najważniejsze są teoretyczne pisma stawiające otwarcie pytanie o rozumienie danego pojęcia, często istotniejsze są praktyczne innowacje w ich użyciu. Pisarze czy ideologowie Narodowej Demokracji sytuują się gdzieś pomiędzy - w swoich bardziej teoretycznych rozważaniach podejmują otwarcie analizę pojęć i praktyki politycznej, przede wszystkim jednak używają (a przez to zmieniają) dane pojęcia w swojej praktyce pisarskiej. Zob. K. Palonen, The Struggle with Time..., s. 87.

45 Tenże, Max Weber als Begriffspolitiker, „Etica \& Politica/Ethics \& Politics” 2005, nr 2.

46 R. Zimand, Uwagi o teorii narodu na marginesie analizy nacjonalistycznej teorii narodu, „Studia Filozoficzne" 1967, nr 4(51), s. 6; R. Wapiński, Narodowa Demokracja 1893-1939. Ze studiów nad dziejami myśli nacjonalistycznej, Warszawa 1980.

47 Przez „polskojęzyczną” sferę publiczną rozumiem całość praktyk językowych dotyczących zjawisk społeczno-politycznych w polskim obszarze językowym jako efektywnie rozgraniczonym obszarze polemik, dyfuzji, translacji i innego rodzaju oddziaływań. Dlatego też przyjmuję, że choć moje docie- 
punktem mniej lub bardziej uświadomionej politycznej identyfikacji i polemicznym elementem odniesienia. Po części endeckie innowacje pojęciowe kształtowały całą polską praktykę językową w zakresie rozumienia (czy dekontestacji) pojęć politycznych i społecznych, wywierając decydujący wpływ na ponadregionalne, wykraczające poza opłotki danej formacji ideologicznej uzusy pojęciowe ${ }^{48}$. Z pewnością dotyczy to pojęcia „naród”49.

W tym szkicu chcę przyjrzeć się, jak przebiegała dekontestacja innego, dość ciasno z „narodem” splecionego, pojęcia. „Polityka” (i jej derywaty) stanowiła jedno z centralnych pojęć specyficznego kompleksu ideologicznego, jaki endecy stworzyli, i innowacja pojęciowa w tym zakresie $\mathrm{w}$ dyskursie endeckim jest tematem poniższych rozważań ${ }^{50}$. W toku polemik, wypracowywania zrębów ideologii „obozu wszechpolskiego" i w zmaganiach z coraz to nowymi sytuacjami na arenie politycznej Królestwa Polskiego, a z czasem i w pozostałych zaborach, sformułowali oni nowatorską wizję polityki, która definiowała podstawowe pojęcia polityczne w sposób niespotykany wcześniej w polskich debatach. Sposób ten miał wyznaczyć ramy rozumienia polityki, jej podmiotów i przedmiotów, rozumienia działań politycznych i aktualnego postępowania politycznego na wiele lat, i to nie tylko pośród członków samej Narodowej

kania dotyczą w zdecydowanej większości Królestwa Polskiego i związanych z tym kontekstem wypowiedzi, to ustalenia mają wagę wykraczającą poza granice jednego z „zaborów”, jako że w polskojęzycznym obiegu intelektualnym obszar ten miał znaczenie kluczowe, a zachodzące na jego terenie procesy kształtowały całą polską sferę polityczno-publiczną.

48 „Obóz narodowy”, jak lubili przedstawicieli tej formacji ideowej określać sami siebie, nie był oczywiście monolitem i stanowiska poszczególnych autorów mogły być odmienne. W kwestii, która mnie w tym artykule interesuje, rozpoznania czołowych ideologów endecji były dość zbieżne. Niemniej jednak zawsze pisanie o narodowodemokratycznym pojęciu polityki czy czymś podobnym jest pewnym uproszczeniem. W analizowanych tekstach nie ma jednak śladów polemiki wewnętrznej, badane wypowiedzi niemal nigdy nie są interdyskursem kierowanym do innych przedstawicieli obozu. Rzadko też są bezpośrednimi polemikami z publikacjami wyrażającymi inne poglądy, analizują inne formacje ideowe i ich poczynania, ale niejako z zewnątrz, jako świat wrogów, a nie polemistów. Fakt ten zresztą był przedmiotem pewnej dumy wśród narodowych demokratów, którzy wychwalali „ogromną jedność ducha i kierunku”. K. Opalinski [Dmowski], Stronnictwa w Królestwie wobec zadań chwili bieżącej. Gtos z Warszawy, „Przegląd Wszechpolski” 1904, nr 11, s. 830.

T. Kizwalter, O nowoczesności narodu...; A. Walicki, The Troubling Legacy of Roman Dmowski, „Dialogue and Universalism" 2011, nr 4.

50 Przedmiotem analizy w niniejszym artykule są programowe artykuły głównych ideologów Narodowej Demokracji z tego okresu, a zatem publiczne ekspresje narodowodemokratycznej filozofii polityki (a nie np. prywatne sądy ich autorów czy ich życie osobiste). Choć dla przekształceń pojęć istotne są ich każdorazowe użycia i nie tylko najbardziej wpływowi pisarze mają w nich swój udział, bez wątpienia programowe, szeroko czytane i komentowane teksty mają w takiej zmianie największe znaczenie. Dlatego spośród bogatego dorobku pisarzy politycznych obozu narodowego omawiam przede wszystkim główne artykuły problemowe, a nie przyczynkarskie interwencje np. z prasy codziennej. Większość takich tekstów została przedrukowana w wydawnictwach zbiorowych wydanych „na gorąco”, z czasem w ramach kodyfikacji ideowych fundamentów ruchu, lub jako krytyczne wydania źródłowe w ostatnich latach. Na ile to możliwe, podaję odnośniki do takich właśnie publikacji ze względu na ich większą dostępność. Tylko jako wydawnictwa zbiorowe widnieją one w spisie literatury. W wypadku tekstów nieprzedrukowanych, ulotek etc. podaję tylko bezpośredni adres bibliograficzny w przypisie dolnym. 
Demokracji. Określone zdefiniowanie pojęć, użycia słów, konstruowane przez nich dyskursy polityczne były też istotnym tworzywem rodzącej się nowoczesnej sfery publicznej w Polsce.

\section{REALIZM I POLITYKA JAKO DZIAŁANIE W CZASIE}

Wraz z krystalizacją doktryny endeckiej związani z tym obozem pisarze polityczni nie tylko formułowali określony program działania, ale też opisywali politykę w kategoriach ogólnych, zwracając uwagę na jej dystynktywne cechy gatunkowe. Zarazem, pisząc o polityce, dawali implicite wyraz temu, jak ją rozumieją, i deklarowali wprost konieczność wprowadzenia pewnych zmian w konceptualizacji polityki dla jej lepszego rozumienia, ale przede wszystkim skuteczniejszego uprawiania. Oczywiście rozstrzygnięcia te były podyktowane pryncypiami ideowymi endeków, a przynajmniej z nimi na podstawowym poziomie niesprzeczne. Zwornikiem myślenia tego obozu ideowego był naród ${ }^{51}$.

Wedle Romana Dmowskiego cała dziedzina polityczna winna być podporządkowana dobru narodu. Absolutyzacja tej formy kolektywnego współbycia została konsekwentnie wcielona w myślenie endecji:

Polityka, jako zakres czynności dotyczacych organizacji zbiorowego życia spoteczeństw, za gtówny swój cel uważać musi dobro catości spotecznej - narodu, oraz utrzymanie i pomyślny rozwój organizacji jego zbiorowego życia - pañstwa ${ }^{52}$.

Zygmunt Balicki szedł jeszcze dalej, uznając rozumowanie w odniesieniu do państwa za schodzącą ze sceny formę myślenia politycznego. To polityka narodowa, prowadzona przez naród jako podstawowy podmiot, ma być teraz - w dobie rodzenia się nacjonalizmu wzniecającego świadomość narodową - jedynym punktem odniesienia:

Naród prawdziwie wspótczesny, o wyodrębnionej silnie indywidualności, myślacy w rzeczach publicznych wtasnym jedynie mózgiem i mający na oku wytacznie sprawy wtasnego bytu i rozwoju, będzie traktowat każdy swój krok w stosunku do państwa, z którym go losy ztaczyty, jako posunięcie w swojej polityce narodowej, nie zaśj jako przejaw polityki państwowej ${ }^{53}$.

51 Być może nawet jest to jedyny w pełni spójny element myślenia tej formacji. R. Wapiński twierdzi, że ideową jedność endecji można zasadniczo sprowadzić do trzech wymiarów, współbieżnych z jej nacjonalizmem. Są to: egoizm narodowy, solidaryzm narodowy oraz imperatyw ciągłej ekspansji narodu, zob. R. Wapiński, Narodowa Demokracja 1893-1939...

52 R. Dmowski, Myśli nowoczesnego Polaka, Wrocław 2002, s. 100. Więcej na temat relacji kategorii narodu do państwa zob. G. Markiewicz, Między państwem obcym a idea państwa wtasnego. Świadomość państwowa polskich elit intelektualnych w latach 1864-1914, Łódź 2010; R. Wapiński, Problem państwa w koncepcjach politycznych obozu narodowego, [w:] Państwo w polskiej myśli politycznej, Wrocław 1988, Polska Myśl Polityczna XIX i XX Wieku, nr 7.

53 Czystość polityki narodowej, [w:] Z. Balicki, Z doby przetomu myśli narodowej, Moskwa 1916, s. 238. Można by uznać tę deklarację za wyraz stanowiska specyficznego dla warunków pozostawania narodu w obrębie „obcych” tworów państwowych. Wcześniejsze uwagi Balickiego sugerują jednak raczej, że postuluje on ogólny odwrót od myślenia państwowego ku myśleniu tylko w kategoriach narodowych, 
Wtórował im potem Stanisław Kozicki, łącząc dodatkowo zasadę narodową z naukowym uzasadnieniem kierunku praktyki politycznej. Polityka, jako system dziatań, majacych na celu zachowanie i rozwój narodowego bytu, jest sztuka, musi sie jednak opierać na wiedzy, przede wszystkim na wiedzy o cztowieku i spoteczeństwie $e^{54}$. Jak widać, poza odniesieniem do absolutu narodowego polityka była przez endeków ujmowana, jak sami to określali, realistycznie.

$\mathrm{Z}$ jednej strony chodziło o stąpanie po ziemi i metodyczne działanie w zadanych warunkach, a nie nieliczące się z możliwościami i konsekwencjami zrywy: [...] politykę narodowa we wszelkim, choćby nader ograniczonym zakresie prowadzić można i należy, stosując ją do granic przez realne warunki zakreślonych ${ }^{55}$. Z drugiej zaś znaczyło to ni mniej, ni więcej, że domena polityczna nie jest podporządkowana jakimś zewnętrznym regułom. Polityk musi wyzbyć się odniesienia normatywnego o tyle, o ile zaciemnia mu ono ocenę bieżącej sytuacji.

Jak pisał „wewnętrzny” historyk Narodowej Demokracji: [...] w życiu politycznym stosować się do tego, co jest, a nie od tego, co być powinno. Odwieczna to zasada madrego realizmu politycznego ${ }^{56}$. $\mathrm{Z}$ postulatu tego wynikało, że dziedzina polityczna jest autonomiczna względem zasad etycznych czy innych prawideł rządzących postępowaniem ludzkim. Polityka nie była dziedziną moralną, ale działanie polityczne nie było też osadzone w wiedzy naukowej. Słowem, nie miało zewnętrznej poręki. Sfera polityczna jest zatem w ujęciu endeckim autonomiczna; rozumiana jest niefundacyjnie. Warto jednak pamiętać, że nie jest też domeną wolności.

Najpełniej steoretyzował relacje między polityką a nauką Zygmunt Balicki. Jako naukowiec konsekwentnie chciał uprawiać naukę wolną od wartości i polityki. Zarazem był jednak czynnym działaczem politycznym związanym z endecją. Choć separacja tych dziedzin nie jest zapewne możliwa, to naukowych pism Balickiego nie da się sprowadzić do ekspresji endeckiej doktryny politycznej. Ów podział działał też w drugą stronę. Pewne uwagi Balickiego z dziedziny socjologii polityki znajdywały wyraz w jego myśleniu politycznym (np. krytyka parlamentaryzmu i relacja między potępianym liberalizmem a bliskim autorowi swoiście pojętym republikanizmem $)^{57}$, polityka nie była jednak w żaden sposób oparta na pozytywnej wiedzy pozyskanej przez Balickiego-naukowca ${ }^{58}$.

Brak odniesienia do zewnętrznych zasad i swoista autonomia sfery politycznej powodują także, że wedle diagnozy endeków niepodobna w polityce wyznaczyć sztywnej

pisze bowiem: Spoteczeństwa spótczesne uczą się dopiero operować myśla w ptaszczyźnie polityki narodowej, na każdym jednak kroku staje im na przeszkodzie nabyta rutyna obracania się w sferze pojęć polityki państwowej. Tamże, s. 237.

54 S. Kozicki, Historia Ligi Narodowej. (Okres 1887-1907), Londyn 1964, s. 451.

55 Dylemat dziejowy, [w:] Z. Balicki, Parlamentaryzm..., s. 516.

56 S. Kozicki, Historia Ligi Narodowej..., s. 447.

57 N. Bończa-Tomaszewski, Demokratyczna geneza nacjonalizmu. Intelektualne korzenie ruchu narodowo-demokratycznego, Warszawa 2001; A. Dawidowicz, Zygmunt Balicki (1858-1916). Dziatacz i teoretyk polskiego nacjonalizmu, Kraków 2006.

58 J. Kurczewska, Naród w socjologii i ideologii polskiej: analiza porównawcza wybranych koncepcji z przetomu XIX i XX wieku, Warszawa 1979, s. 215. 
strategii czy jakiegokolwiek gotowego do zastosowania algorytmu. Polityka to raczej sztuka adaptatywnego działania w zadanych okolicznościach. Nie można pozwolić na to, by raz obrane zasady skostniały w postaci martwych dogmatów, które w nowych okolicznościach uniemożliwiają sprawne działanie. Polityka zatem nie jest dziedziną rządzoną określonymi prawami, a raczej praktycznym działaniem w konkretnych warunkach. Ci, którzy zamykają się w dogmatach i formułach, będących parodią dawnych zasad $^{59}$, nie mogą stawić czoła wyzwaniom, popadają w martwotę doktryny i nie są już defacto politykami.

Z faktu, że nie ma ogólnych zasad, którymi powinien kierować się polityk, wynika, iż wszystkie środki, któremi polityka rozporzadza, sq odpowiednie w pewnych warunkach. Działanie dostosowuje się do zaistniałych zdarzeń: $w$ tym względzie nie ma $\dot{z} a d n y c h$ prawidet statych, żadnych zasad. W pewnych okolicznościach rozum polityczny wskazuje uzycie środków rewolucyjnych, takich nawet, jak zamachy terrorystyczne ${ }^{60}$. Warto pamiętać, że słowa te pochodzą od zaprzysięgłego wroga destabilizacji, anarchii, rewolucji, który jednak chce działać wyłącznie na podstawie kalkulacji sił, swoiście pojętej narodowej racji stanu, a nie podług apriorycznych zasad ${ }^{61}$. Stąd solenne zapewnienia, że obóz narodowy nie jest obozem zachowawczym czy ugodowym, lecz nie jest też powstańczy ani rewolucyjny:

Istnieje rzeczywiście w spoteczeństwie naszem przeciwieństwo, a nawet walka dwóch kierunków, dwóch zasad. Jest to walka myśli politycznej z myśla apolityczna, walka realizmu politycznego z wszelkim doktrynerstwem rewolucyjnem, ugodowem, humanitarnem itd. ${ }^{62}$

Pojawia się tu specyficzne dla endecji zestawienie tego, co polityczne, a zatem celowe i dążące do celu, choć stawiające czoła przygodności życia, z tym, co apolityczne, niezorganizowane albo - przeciwnie - zastygłe w martwej doktrynie. Prawdziwie polityczna strategia jest wyborem rozumu politycznego, chciałoby się rzec, domeną niemal Machiavelliańskiej virtú. Podstawowym credo endeckiej polityki jest „realizm”, a wrogiem „doktryna”. Liczy się tylko walka o naród i elastyczna adaptacja do okoliczności:

$W$ dzisiejszym potożeniu polityka narodowa musi, o ile to możliwe, zostawić sobie wszystkie drogi otwartemi, wobec tego, że żadna nie jest pewna; musi być możliwie wolna od wszelkich ztudzeń i oprzędzeń, ażeby umiata każda sprzyjajaca okoliczność na korzyść sprawy narodowej wyzyskać. Nie może ona pchać narodu cata sita na jedna droge, gdy to jest potaczone z zamknięciem mu dróg innych; nie może stawiać na kartę mniejszej lub większej ilości dobra narodowego dla jakiejśpowziętej z góry myśli. Stowem, musi ona więcej niz kiedykolwiek być, być realna polityka interesu narodowego, nie zaśpolityka oderwanych kombinacyj, musi być dziataniem dla ojczyzny, nie dla doktryny ${ }^{63}$.

59 Wobec nowego potożenia, [w:] Z. Balicki, Parlamentaryzm..., s. 480.

Doktryna i realizm w polityce, [w:] R. Dmowski, Pisma, t. 3: Dziesięć lat walki, Częstochowa 1938, s. 210 .

${ }_{61}$ Na temat tego elementu u Popławskiego zob. A. Puszkow-Bańka, Polska i Polacy w myśli narodowej demokracji na przetomie XIX i XX wieku (Jan Ludwik Poptawski, Zygmunt Balicki, Roman Dmowski), Kraków 2013, s. 94.

62 Doktryna i realizm w polityce, [w:] R. Dmowski, Pisma, t. 3, s. 209.

63 Ojczyzna i doktryna, [w:] R. Dmowski, Pisma, t. 3, s. 46. 
Również w pismach Balickiego pojawia się specyficzny nowoczesny machiawelizm. Podobnie jak w tekstach innych ideologów narodowej demokracji, i w jego tekstach można wyodrębnić w zasadzie dwa rodzaje machiawelizmu. Pierwszy to raczej machiawelizm wulgarny, sprowadzający się do zasady, że cel uświęca środki. Pragmatyczność i amoralność myśli Balickiego każe mu odrzucić „etykę ideałów”; podobnie jak dla Dmowskiego, podstawą jest imperatyw skuteczności i siły ${ }^{64}$. Takie przedstawienie sprawy stawia ideologów Narodowej Demokracji w szeregu pionierów uwolnionego z pęt moralności realizmu politycznego i przedstawicieli nowożytnej koncepcji racji stanu ${ }^{65}$.

W specyficznym realizmie endecji można doszukać się też wizji polityki jako dziedziny działania praktycznego w zadanych okolicznościach. W polityce jak w szachach, jak na polu bitwy, potrzeba określić z góry normy, które się wysuwa, jako stanowisko, jako pozycje do zdobycia, ilosí́ sit, które mają być w ruch puszczone $e^{66}$. Umiejętnością polityka w takim ujęciu jest właśnie radzenie sobie z okolicznościami i osiąganie rezultatów jak najlepszych dla swojej wspólnoty. Sztuka polityki to „sprężyste” dostosowanie się do okoliczności, wykorzystywanie sposobności: Stanowisko polityczne w każdej kwestii, przywiazane do uktadu sit i stosunków w danym czasie i miejscu, zmieniać się musi wraz ze zmiana warunków $[\ldots]^{67}$. Nie jest to zatem odległe od virtu rozumianej jako zdolność zmagania się z fortuną i przekształcania okoliczności na swoją korzyść, jakie możemy znaleźć w rozumie politycznym Machiavellego.

Florentyński filozof musiał odwołać się do mitycznej fortuny, by skonceptualizować przygodność ludzkiego świata i odpowiadającą jej racjonalność polityczną. Fortuna wskazywała dokładnie na aleatoryczność porządku, w którym żyjemy, a zatem i adekwatnej politycznej strategii, która nie może posiłkować się rozstrzygnięciami apriorycznej teorii politycznej. Działanie polityczne czynione jest ponadto bez znajomości jego konsekwencji. Inaugurując akcję polityczną, nie można mieć pewności, że zakończy się ona zgodnie z powziętymi zamiarami ${ }^{68}$. Ta złożoność świata i wielowymiarowa naddeterminacja ludzkich działań, niemożliwość przewidywania, a nawet kategorycznego opisu jest podstawową kondycją polityki, która znajduje wyraz w pojęciu fortuny ${ }^{69}$.

64 Egoizm narodowy wobec etyki, [w:] Z. Balicki, Parlamentaryzm...; A. Puszkow-Bańka, Polska i Polacy..., s. 208.

${ }_{65}$ W polskiej tradycji myślenia politycznego jest to postawa zdecydowanie mniejszościowa. W obliczu utrzymującej się poarystotelesowskiej i tomistycznej wizji polityki nowożytna koncepcja racji stanu ukierunkowana na zachowanie państwa jako takiego, a nie realizację heteronomicznych celów i transcendentnie uzasadnionego ideału dobrego życia nie była zjawiskiem częstym. Zob. A. Rzegocki, Racja stanu a polska tradycja..., s. 221-222, 256-263, 299-306. O Machiavellim jako kluczowej figurze w rozwoju realizmu politycznego pisze P. Kimla, Historycy-politycy jako źródto realizmu politycznego. Tukidydes - Polibiusz - Machiavelli, Kraków 2009.

66 Umiarkowanie w polityce, [w:] Z. Balicki, Z doby przetomu..., s. 221.

67 Tamże, s. 225-226.

68 N. Machiavelli, Książę. Rozważania nad pierwszym dziesięcioksięgiem historii Rzymu Liwiusza, Warszawa 2008.

69 H.F. Pitkin, Fortune Is a Woman. Gender and Politics in the Thought of Niccolo Machiavelli. With a New Afterword, Chicago 1999; Q. Skinner, Machiavelli, Oxford-New York 1981. 
Podobna wizja polityki jako mierzenia się z okolicznościami i wyzyskiwania najlepszych możliwości do realizacji swoich celów nie była obca endecji. Sytuacja w szesnastowiecznej Florencji zmusiła Machiavellego do przemyślenia na nowo podstaw myśli republikańskiej w sposób umożliwiający stawienie czoła kontyngencji polityki ${ }^{70}$. Endecy także podjęli refleksję nad formami działania politycznego adekwatnego do aleatorycznych okoliczności. Dla nich podobnym momentem było fiasko polityki międzynarodowej opartej na wartościach i sytuacja pozostawania poza prawem dążeń niepodległościowych w Królestwie Polskim. Dodatkowym kontekstem była konieczność wymyślenia od nowa form wspólnoty mogącej stanowić przedmiot analizy i podmiot działania politycznego ${ }^{71}$.

W zaistniałej sytuacji endecy porzucili sztywne kodyfikacje postępowania politycznego i zewnętrzne sankcje etyczne, rozwijając specyficzny rodzaj politycznego realizmu okiełznującego przygodność sytuacji. W tym wymiarze bez wątpienia topika służąca opisaniu polityki jest związana z konceptualizacją czasową. „Polityka” to działanie w czasie; nie jest opisywana przez zbiór reguł, ale raczej przez specyficzne adaptatywne nastawienie zdolne mierzyć się z zawsze zmiennymi okolicznościami. Nie oznacza to jednak całkowitej rezygnacji z ujęcia przestrzennego, choć odnosi się ono raczej do klas problemów, kategorii działania i cech polityka, które wyznaczają pewną sferę, domenę czy dziedzinę polityki.

\section{DZIEDZINA POLITYCZNA NARODOWEJ DEMOKRACJI}

Konsekwentne zastosowanie tak rozumianego realizmu i przemyślenie jego następstw doprowadziło endeków do sformułowania nowatorskiej w kontekście polskim koncepcji autonomii sfery politycznej. Polityka była ujmowana przede wszystkim jako działanie celowe, odbywające się w określonych, specyficznych dla niej ramach ${ }^{72}$. Przykładowo wedle Balickiego polityka - to celowe i planowe, panujace nad soba i nad okolicznościami dziatanie na zewnatrz ${ }^{73}$. Przy okazji analizy tendencji powstańczych Balicki jasno definiuje działanie polityczne jako celowe i podejmowane wobec zastanych warunków. Podążanie zatem za z góry określonymi celami bez względu na szansę ich realizacji wprost określa jako postulat apolityczny ${ }^{74}$. Takie celowe działanie polityczne jest przede wszystkim właściwe kolektywnym bytom, takim jak najważniejszy dla tego kręgu ideowego - naród. Naród musi prowadzić politykę, jeżeli chce żyć, a nie się cofać

70 Wyzwanie to i odpowiedź, jakiej udzielił Machiavelli, opracował J.G.A. Pocock, The Machiavellian Moment Florentine Political Thought and the Atlantic Republican Tradition, Princeton 2003.

71 W. Marzec, Ponowne obsadzenie pustego miejsca - endecki naród i polityczna nowoczesność, „Hybris” 2014, nr 24; B. Porter, Who Is a Pole and Where Is Poland? Territory and Nation in the Rhetoric of Polish National Democracy before 1905, „Slavic Review” 1992, Vol. 51, nr 4; tenże, Gdy nacjonalizm zacząt nienawidzić. Wyobrażenia nowoczesnej polityki w dziewiętnastowiecznej Polsce, Sejny 2011.

72 Polityka nerwowa, [w:] J.L. Popławski, Pisma polityczne, Warszawa 1910, s. 20.

73 Charaktery a życie polityczne, [w:] Z. Balicki, Parlamentaryzm..., s. 386.

74 Przeobrażenie metod walki, [w:] Z. Balicki, Parlamentaryzm..., s. 491. 
i rozkładać stopniowo, jeśli chce osiągnąć zdobycze i budować swoją przyszłość, a nie tylko marzyć o niej. A zatem naród politykę prowadzić może, powinien i musi ${ }^{75}$.

Wyłonienie się owej politycznej dziedziny, domeny działania politycznego, było dla endeków bezpośrednim wynikiem zachodzących przemian społecznych i równoległej transformacji myślenia publicznego, które zaczęło wykształcać świadomy rozum polityczny. Nie bez znaczenia dla krystalizacji tego ujęcia była rewolucja 1905. W lutym 1905 r. Dmowski pisat: Program demokratyczno-narodowy, program par excellence polityczny, na powaznych koncepcjach politycznych oparty, jest zrozumiaty tylko dla pokolenia, które wyrosto w atmosferze politycznej, od mtodych lat interesowato się zagadnieniamiz tej dziedziny ${ }^{76}$.

Z owej politycznej atmosfery, która narastała już od pewnego czasu, wyrastał postulat kształcenia specjalnych cech i umiejętności, jakich autonomicznie ujmowana dziedzina polityczna wymagała. Działanie polityczne rządziło się sobie właściwym rozumem politycznym, a zatem polityk winien posiadać specyficzne cechy i kompetencje. Na dodatek - jako że niepodobna wymienić jednoznacznych reguł rządzących działaniem politycznym - nie mógł ich w prosty sposób nabyć. Polityka to raczej domena wiedzy praktycznej, rozpoznania z dziedziny phronesis; jak dobrać środki do celów, jak działać w danych okolicznościach i jak wyzyskać nadarzające się okazje. Dmowski już nieco wcześniej dawał tu wyraźne - choć niełatwe do naśladowania - wskazówki:

Polityka jest najbardziej skomplikowana dziedzina ludzkiego ducha, sieggająca w jego gtębiny, wciagająca w gręnajróżnorodniejsze czynniki moralne i umystowe. Od nauki tym się różni, że najważniejszych jej podstaw nie można się z książek nauczyć, od sztuki tym, że nie wystarcza wniej talent $i$ wprawa techniczna. Polityk, w powaznym tego stowa znaczeniu, musi mieć nie tylko zapas wiedzy urzędowej ze swego zakresu, wiedzy ujętej w formuty i spisanej, nie tylko musi znać pewne, ogólnie przyjęte metody dziatania, nie tylko musi posiadać pewna miare talentu, ale także musi droga samoistnej pracy wtasnym umystem opanować caty szereg zjawisk, których żadna wiedza urzędowa dotychczas nie objęta, musi mieć swoją, samoistna miarę dla różnych wartości spotecznych, musi wreszcie posiadać wysokie pierwiastki charakteru i zasady moralne, bez których w życiu prywatnym, na innych polach pracy można się obejść i nawet być wzorem dla otoczenia. Robić źle politykę może każdy, ale nie często się trafiaja ci, którzy ją dobrze robić umieją7.

Ci, którzy umieją parać się polityką, byli coraz bardziej potrzebni. Zarazem wejście w polityczną nowoczesność oraz rosnąca polaryzacja pola politycznego czynity sformułowanie skutecznej doktryny politycznej, jak i wytworzenie grupy ludzi zdolnej ją wcielać w życie niezbędnymi. Zaistniałe zdarzenia umożliwiły pojawienie się sfery politycznej i pomogły w wykrystalizowaniu obozów politycznych. W tym miejscu ujęcie sfery politycznej jako domeny, w której panują relacje specyficzne dla politycznego działania (a zatem przestrzenna projekcja konceptualizacji czasowej), nabrało nowych walorów. Fakt, iż przynależność do niej definiowana była przez działanie, umożliwił określanie,

75 Dylemat dziejowy, s. 503, 514.

76 Polityczna konieczność, [w:] R. Dmowski, Pisma, t. 3, s. 380.

77 R. Dmowski, Myśli nowoczesnego Polaka, s. 86. 
jakie podmioty i ideologie prawdziwie do niej przynależą. Towarzyszyło temu przemyślenie istoty różnicy politycznej i stosunku do antagonistów.

\section{POLITYCZNOŚĆ MYŚLI ENDECKIEJ I RÓŻNICA POLITYCZNA}

Wykształcenie się sfery politycznej oznaczało też dla endeków krystalizację stanowisk politycznych. Ich ogólnie antagonistyczna wizja stosunków społecznych bez wątpienia nie była tu bez znaczenia. W momencie uruchomienia mechanizmów politycznych i mobilizacji na masową skalę w czasie rewolucji stało się dla nich jasne, że przyszedł czas polaryzacji stanowisk, obrania ostrego kursu zmierzającego do eliminacji przeciwnika i konsolidacji własnych szeregów. Każdy dziś, kto chce brać udziat w obywatelskim życiu, musi się oświadczyć, czego chce dla kraju, z kim idzie w polityce. Trzeba stanąć pod sztandarem ${ }^{78}$, pisał Dmowski. Taka dyscyplinująca wizja polityki stała się podstawą bieżących działań endeckich instytucji w okresie 1905-1907 i latach następnych. Dmowski doskonale zdawał sobie sprawę z postępującej krystalizacji politycznych pozycji i nie stronił od pogłębiania narastającej polaryzacji. Gdy endecja proklamowała kompleksowy program działania, głosem nieznoszącym sprzeciwu nawoływał do bezwzględnego opowiedzenia się po jednej ze stron. Ową zdefiniowaną, niejako wyrażającą całą polskość w hegemonicznym stosunku podług figury katachrezy, siłą była oczywiście Narodowa Demokracja. Nie znajdowano już miejsca dla apolitycznych (czy prepolitycznych) autorytetów, nadszedł czas nowoczesnej polityki partyjnej opartej na dość bezwzględnej walce politycznej:

Minąt już czas na bezpartyjnych i międzypartyjnych superarbitrów, na grupy polityczne, tączace się do pojedynczego czynu, po którym się rozpraszaja, zwalniając się zarazem od odpowiedzialności za swój krok przed opinia, na stronnictwa, które wiedza jedynie, czego chca lub czego nie chca. W poważnej chwili dziejowej, która dziś nadeszta, polityka narodowa wymaga pewnej ręki u swego steru: trzeba mieć świadomość celu, do którego się zmierza, trzeba wiedzieć, jaka droga ma do niego prowadzić. Trzeba się zgodzić na nasze cele i nasze drogi, albo też inne wyraźnie wskazać ${ }^{79}$.

Dmowski proklamował bezalternatywny program, który miał bezpośrednio wyrażać polskość. Jego wizja polityki stała się bardzo antagonistyczna i raczej nie uwzględniała demokratycznego pluralizmu jako konstytutywnego czynnika empirycznej realizacji tego, co polityczne. Warto jednak zauważyć, że mimo wszystko uznaje on politykę partyjną za formę wyrazu nowoczesnej kondycji politycznej. Apologia polityczności dotyczy zdecydowanego i celowego działania i w gruncie rzeczy nie dotyka kwestii, na ile to właśnie różne wizje prowadzenia polityki są nieodłączną częścią nowoczesnej sfery politycznej. Rozstrzygnięcie relacji między akceptacją pluralizmu (także raczej realistycznie konstatującą fakt) a przekonaniem o dostępie do „właściwej” politycznej prawdy i „przejrzystej” reprezentacji wspólnoty ma miejsce na innym poziomie niż zdefiniowanie polityki jako takiej.

\footnotetext{
78 Nasze cele i nasze drogi, [w:] R. Dmowski, Pisma, t. 3, s. 378.

79 Polityczna konieczność, [w:] R. Dmowski, Pisma, t. 3.
} 
Nowoczesne pojęcie polityki często jest rozdarte. Choć w wielu wypadkach formułowane jest jako podstawa pewnej, wyzbytej dążenia do dobra czy urzeczywistnienia ludzkiej natury, nauki, w wielu ujęciach zachowuje pewien „osad” poarystotelesowskiego dziedzictwa. $\mathrm{Na}$ wiele sposobów różni myśliciele i ideologowie starali się uzasadniać bliski sobie kierunek działań, zarazem jednak utrzymać neutralny i obiektywistyczny wydźwięk własnej nauki o polityce ${ }^{80}$. Ideologowie Narodowej Demokracji z Dmowskim na czele nie są tu wyjątkiem. Ten ostatni rozwiązuje problem w ten sposób, że choć dopuszcza wielość programów politycznych, to w gruncie rzeczy prezentuje myśl Narodowej Demokracji jako jedyną prawdziwie polityczną. Polityczną, to jest dorastającą do jego własnej definicji działania politycznego jako realistycznego i zorientowanego na cel. Inne kierunki ideowe nie zasługiwały na miano politycznych. Tak zwana polityka ugodowa ma to wspólnego z polityka socjalistyczna, że wtaściwie polityka nie jest ${ }^{81}$, pisat.

$\mathrm{Z}$ jednej strony Dmowski pragnął być analitykiem sfery politycznej i opisać tę domenę życia społecznego, wskazując na przynależne jej zasady. W tym wymiarze wznosił się niejako ponad partykularne stanowisko własnej opcji ideowej. $Z$ drugiej jednak strony momentalnie sprowadzał inne kierunki do roli niepolitycznych, aberracyjnych urojeń. Zawłaszcza tym samym całą domenę polityki dla własnego programu i uniwersalizuje go jako nie tylko prawomocnie wyrażający polskość, ale i jedyny program realnie polityczny. Wprowadza więc różnicę polityczną i niemal tym samym gestem anuluje ją na innym poziomie.

Argument o polityczności własnego stanowiska ma zatem na celu jego depolityzację (już w innym sensie, związanym z naturalizacją tegoż stanowiska), jako jedynego realnego, możliwego i odpowiadającego interesom narodu. Mimo że niefundacyjne podejście prowadzi endeków do uznania, że [...] polityka nie jest gra uczuć, lecz gra sit, interesów i celów ${ }^{82}$, to jednocześnie próbują oni zdepolityzować spór i nie uznać odmiennego stanowiska za realną alternatywę, wynikającą z odmiennej politycznej decyzji. Skoro polityka jest działaniem celowym, to na płaszczyźnie celów określana może być ocena czynów i koniec końców ich „polityczność”. Jak głosiła jedna z endeckich odezw politycznych: Zdarza się, że ludzie oceniając te wypadki zapominaja, że każdy czyn musi mieć swój cel, iż musi go mieć zwtaszcza tam, gdzie idzie o losy ojczyzny, że nie mając go, może stać się zbrodnią $[\ldots]^{83}$. Podwójny ruch polityzacji i jednoczesnej depolityzacji wyrażany jest w zdwojonej topice wykorzystywanej do opisu sfery politycznej. Z jednej strony występuje polityka rozumiana niespecyficznie jako dziatanie o zdefiniowanych celach, $\mathrm{z}$ drugiej polityka odnosi do określonego rodzaju dziatania przypisywanego wła-

80 Przykłady z historii dziewiętnastowiecznej niemieckiej myśli politycznej podaje V. Sellin, Politik.

81 K. Opaliński [Dmowski], Czego nam potrzeba. Gtos z Warszawy, „Przegląd Wszechpolski” 1904, $\mathrm{nr} 12$, s. 838. Takie rozumowanie upowszechniło się także u innych reprezentantów ruchu. Publicysta ukrywający się pod pseudonimem „Stary narodowiec” pisał nieco później: Mówiąc dziś o polityce naszego kraju, trzeba wtaściwie mówić o polityce Demokracji Narodowej. „Przegląd Narodowy” 1908, nr 1, s. 7.

82 Dylemat dziejowy, s. 513.

83 Odezwa Komitetu Centralnego Ligi Narodowej, 8 II 1905, cyt. za: S. Kozicki, Historia Ligi Narodowej..., s. 552. 
snej formacji. Są one powiązane - endecja jako jedyna realizuje polityczność działania ale nie tożsame. Właśnie to rozsunięcie pozwala na ów podwójny ruch polityzacji/depolityzacji.

Podobne napięcie cechowało rozumienie polityki w kontekście celów narodowych. Sformulowanie „polityka narodowa” jest bodaj najczęstsza kolokacją związaną z pojęciem polityki w pisarstwie endecji, będąc nijako łącznikiem utożsamiającym generyczne pojęcie „prawdziwej” polityki, wartej tego miana, z własną, konkretną polityką „obozu narodowego”, jak wówczas mawiano. Sformułowanie to oczywiście wskazuje także na fakt, że „obóz narodowy” jest naturalnym i jedynym narodu reprezentantem, a zarazem jest jedynym podmiotem zdolnym działać politycznie. $Z$ jednej strony endecy uznawali - a nawet niekiedy afirmowali - wyostrzenie różnic politycznych czy antagonistycznego wymiaru życia społecznego, z drugiej jednak prawdziwie polityczny kierunek mógł według nich reprezentować jeden rodzaj wspólnoty ludzkiej - naród.

W obrębie zaś celów narodowych nie było miejsca na różnice zdań. Wewnątrz reprezentacji narodu różnica polityczna nie powinna istnieć, a nawet więcej - w zasadzie nie istnieje $\mathrm{z}$ definicji. Balicki proponował istnienie tylko jednego programu narodowego, w którym partie i stanowiska polityczne zastępuje wspólna praca na rzecz naro$d u$ - program ten $[. .$.$] jest ogólnonarodowy i$ niczego stronniczego $w$ sobie nie zawiera ${ }^{84}$. Jest tak na mocy założenia, że to endecja w pełni wyraża program narodowy, który sama powołała do życia.

Sam naród z kolei w coraz większym stopniu pojmowany był przez endeków jako unitarna, organiczna całość złożona ze zróżnicowanych, ale działających w idealnej harmonii części ${ }^{85}$. Dlatego też plan [...] postępowania, który w danej chwili uzyska aprobatę ogótu, będzie zaprowadzony z cata stanowczościa kierującej nim jednolitej woli ${ }^{86}$. Nie ma więc możliwości zaistnienia sporu politycznego wewnątrz. Osłabiłoby to wspólnotę, było obcym tworem w narodowym ciele. Dlatego też należy unikać rozpędzania nabrzmiatych wrzodów na ciele organizmu narodowego, tem spokojniej i normalniej odbywać się może jego rozwój $j^{87}$. Gdy spór się pojawia, oznacza to działanie sił antynarodowych (rozumianych w mocnym, substancjalnym sensie, a nie jako określenie przeciwników programu narodowego) lub w najlepszym razie kryzys narodu ${ }^{88}$.

Nie ma zatem możliwości sformułowania programu narodowego poza ruchem endeckim, który prawomocnie wyraża interesy wspólnoty narodowej i ucieleśnia naród jako podmiot polityczny. Jeśli jakaś myśl nie idzie po linii doktryny endeckiej, to po

84 Jedność wewnętrzna polityki narodowej, [w:] Z. Balicki, Z doby przetomu..., s. 97. Zwłaszcza wśród narodów prawdziwie wspótczesnych a pozbawionych samoistności państwowej nie powinno być stronnictw politycznych. Czystość polityki narodowej, s. 239.

85 A. Dawidowicz, Zygmunt Balicki (1858-1916)..., s. 220; G. Krzywiec, Szowinizm po polsku. Przypadek Romana Dmowskiego (1886-1905), Warszawa 2009; R. Zimand, Uwagi o teorii narodu...

86 Jedność wewnętrzna polityki narodowej, [w:] Z. Balicki, Z doby przetomu..., s. 100.

87 Zachowanie typu narodowego, [w:] Z. Balicki, Z doby przetomu..., s. 192.

88

Polityka narodowa bowiem musi oznaczać zachowanie typu narodowego i realizowanie narodowej substancji i jej gtębokich wtasności. Zachowanie typu narodowego, [w:] Z. Balicki, Z doby przetomu... 
prostu nie jest narodowa. Nie jest nawet polityczna. Polityka narodowa jest jedna, nie ma tu frakcyjności czy różnicy politycznej. Jeśli ścierają się dwa stronnictwa, to pewne jest, że nie mogą oba równocześnie wyrażać interesu narodu.

Nie może być dwóch krzyżujacych się i wykluczających wzajemnie mandatów narodowych i dwóch wzajemnie paraliżjących siępolityk; moga być dwie odrębne polityki zwalczajacych sie stronnictw, ale wtedy nie będzie polityki narodowej. Polityka narodowa musi byćjednolita, występujaca wimieniu narodu i obejmujaca catość jego zadañ ${ }^{89}$.

Takie postawienie sprawy umożliwiło, czy może nawet wymusiło, silną „racjalizację" różnicy politycznej, częste w publicystyce endeckiej zrównanie politycznych przeciwników z wrogimi narodowi, „niepolskimi” (najczęściej żydowskimi) siłami ${ }^{90}$. Proces ten był dobrze widoczny w kolejnych kampaniach do carskiej Dumy, coraz silniej naznaczonych politycznym antysemityzmem ${ }^{91}$. Balicki dostarczył nawet rozbudowanego uzasadnienia teoretycznego, proponując rasową teorię partii politycznych:

[...] najgtębszym, najistotniejszym podktadem podziatu na stronnictwa są różnice rasowe; na nich dopiero szczepia się cechy drugorzędne, na tle życia spotecznego powstate. Ludzie należacy do jednej rasy etnicznej, mają we krwi i w instynkcie pewien typ narodu [...] tworza więc z natury rzeczy stronnictwo polityczne odrębne, przeciwstawiajac się stronnictwom, noszacym w sobie inne podtoże rasowe $[. . .]^{92}$.

Polityczna oscylacja dotycząca depolityzacji własnej pozycji poprzez określenie jej jako jedynej prawdziwie politycznej wiązała się też ze zmianą domniemanego horyzontu zmiany. Stosunek do przyszłych celów zaczął być ściśle nowoczesny. Mam na myśli daleko idącą problematyzację tego, do czego można dążyć w działaniu politycznym, i tego, co musi stanowić tego dążenia pozornie nierealny cel.

\section{HORYZONT ZMIAN I ZMIANA HORYZONTU}

Każda konceptualizacja działania politycznego jako realizującego się w czasie obejmuje też pomyślenie horyzontu zmiany. Myślenie polityczne, jako samo w sobie nowoczesne (nie chodzi tu o konkretne ramy czasowe, w jakich zaistniało, ale jego charakterystykę teoretyczno-formalną), musi obejmować problematyzację relacji między tym,

89 Dylemat dziejowy, s. 513.

90 Taką rasowo-etniczną analizę przeciwników politycznych (w tym przypadku socjalistów) zaproponował Dmowski np. w tekście Historia szlachetnego socjalisty, [w:] B. Toruńczyk, Narodowa Demokracja. Antologia myśli politycznej "Przeglądu Wszechpolskiego” 1895-1905, Londyn 1983. Zob. też tekst B. Toruńczyk, Pótpolacy, [w:] R. Dmowski, Pisma, t. 3; oraz Kwestia robotnicza w programie demokratyczno-narodowym, „Przegląd Wszechpolski” 1903, nr 4, s. 249-250.

91 Z bogatej literatury na ten temat zob. zwłaszcza Antisemitism and Its Opponents in Modern Poland, red. R. Blobaum, Ithaca 2005; W. Marzec, What Bears Witness of the Failed Revolution? The Rise of Political Antisemitism during the 1905-1907 Revolution in the Kingdom of Poland, „Eastern European Politics and Societies" 2016, Vol. 30, nr 1; S. Ury, Barricades and Banners. The Revolution of 1905 and the Transformation of Warsaw Jewry, Stanford 2012, rozdz. 6; T.R. Weeks, Fanning the Flames. Jews in the Warsaw Press, 1905-1912, „East European Jewish Affairs” 1998, Vol. 28, nr 2. 
co dane, a przyszłością - również wtedy, gdy widzi przyszłość jako dokładne zachowanie teraźniejszości ${ }^{93}$. $Z$ tego względu w myśleniu politycznym pojawiają się różnie ujęte odniesienia do realności przyszłych celów. Wizja niemożliwego może być warunkiem jakiejkolwiek zmiany tego, co jest. Albo też polityka widziana jest jako zmaganie się z realnością, stawianie tylko takich celów, jakie możliwe są do realizacji z pomocą rozporządzalnych środków. I na odwrót: postuluje się dobieranie tylko takich środków, jakie w danych warunkach mogą realnie prowadzić do obranego celu4.

Endeckie myślenie polityczne łączy oba te wymiary. Z jednej strony, jak widzieliśmy, jest otwarcie „realistyczne”. Programowo stroni od marzeń sennych w polityce ${ }^{95} . \mathrm{Z}$ drugiej jednak konsekwentnie wykracza poza horyzont wydarzeń uznawanych powszechnie za możliwe wówczas, gdy owo myślenie się formowało. Narodowi demokraci uznawali zbudowanie polskiej państwowości za cel długofalowy swoich zabiegów, w przekonaniu, że tylko we własnych strukturach państwowych naród może się prawidłowo rozwijaćcí. Nie było to w ówczesnym powszechnym mniemaniu celem bezpośrednio możliwym do zrealizowania. Możliwość endeckiej polityki realnej jest w gruncie rzeczy warunkowana proklamowaniem pozornie nierealnego celu. I odwrotnie, dojście do tego nierealnego celu jest możliwe tylko dzięki realistycznemu ujęciu bieżących działań. Postulatem politycznym na dany czas $i$ w danych warunkach jest to, co można bezpośrednio osiagnać lub wywalczyć, a co pod żadnym względem nie przesądza o dalszych etapach $w$ rozwoju dążeńn ${ }^{97}$.

Ujmując rzecz nieco inaczej, zmaganie z tym, co jest, i dążenie do realnych celów, możliwych do urzeczywistnienia w danych warunkach, daje możliwość przekroczenia tego, co jawi się w dalszej perspektywie czasowej jako nieuniknione. Nieliczenie się z realiami powoduje wieczne odroczenie zmiany, rozwijanie marzeń i mitów, a nie realne działanie. Niemniej jednak rezygnacja z nierealnego celu pozostawiłaby politykę w kręgu jałowych zabiegów nieprzekształcających świata (od którego akceptacji endecja była, przynajmniej początkowo, jak najdalsza). Nie jest to więc Weberowskie credo

93 R. Koselleck, Zur historisch-politischen Semantik asymmetrischer Gegenbegriffe, [w:] Vergangene Zukunft, Frankfurt am Main 1979; tenże, Warstwy czasu...

94 K. Palonen, The Struggle with Time..., s. 216-134.

95 Marzenia senne w polityce, [w:] Z. Balicki, $Z$ doby przetomu.... Właściwe dobremu politykowi umiarkowanie to trzeźwa ocena tego, co można zdobyć - a zatem o co należy zabiegać. Zob. Umiarkowanie wpolityce.

96 Na temat roli niepodległości i państwa w życiu narodowym zob. R. Dmowski, Myśli nowoczesnego Polaka, s. 18, 67. Za sprawą Dmowskiego nie zamieszczono bezpośredniego nawoływania do walki o niepodległość w programach SDN, by nie dawać pretekstu do represji ze strony rządów zaborczych. Dlatego też np. w programie SDN z 1903 r. była raczej mowa o wyższych formach samoistnego bytu państwowego. Zob. J.L. Popławski, Program Stronnictwa Demokratyczno-Narodowego, [w:] B. Toruńczyk, Narodowa Demokracja... W innym miejscu Dmowski pisal, że: [...] polityka narodowa [...] staje na gruncie [...] rozwijania pierwiastków państwowości polskiej. Anachronizm polityczny, „Przegląd Wszechpolski” 1904, nr 7, s. 486. Na temat niejawnej obecności kwestii niepodległości w programach SDN podyktowanej legalizmem oraz prywatnych zapatrywań Dmowskiego na długofalowy program zob. M. Kułakowski, Roman Dmowski w świetle listów i wspomnień, Londyn 1968, s. 125; A. Micewski, Roman Dmowski, Warszawa 1971, s. 48-49, 65; R. Wapiński, Roman Dmowski, Lublin 1989, s. 115. 
nakazujące dążenie do niemożliwego, widziane jako jedyna możliwość przekroczenia status qu $0^{98}$. To raczej jego odwrócenie wiążące zmianę tego, co jest, ze stałym jego przekraczaniem w możliwym do pomyślenia zakresie. Chciejmy tego, co jest wszędzie, bo tylko tą droga możemy osiagną́ to, czego jeszcze nie ma gdzie indziej99, możemy się dowiedzieć od Zygmunta Balickiego.

\section{KONSEKWENCJE ZMIANY POJĘCIOWEJ}

Trudno wskazać bezpośrednie związki przyczynowe między konkretnymi wypowiedziami a ogólną zmianą semantyki pojęcia. Z pewnością jednak przedstawione tu zmagania z pojęciem polityki były jaką́s częścią zachodzącej wówczas ogólniejszej zmiany pojęciowej. Pierwsze miarodajne źródła podające słownikowe definicje pojęcia polityki zaraz po omawianym okresie są wyraźnie inne od tych je poprzedzających. Podstawowa międzywojenna encyklopedia jako pierwsza historyzuje pojęcie polityki wedle podziału na gałąź wiedzy vs. metoda działania dla osiągnięcia pewnych celów. Określenie pierwsze jest uznawane za archaiczne ${ }^{100}$. Jako główne podane jest znaczenie nowe: Pod wyrazem polityka powszechnie rozumie się metodę, za pomoca której bądź panstwo, bądź grupy, które maja wptyw na państwo, osiagaja swój cel ${ }^{101}$. Encyklopedii wtóruje ówczesny słownik, wedle którego polityka to sztuka rządzenia państwem, utrzymania i wyzyskania stosunków [...] sprawy, interesy polityczne, zasada, sposób albo system postępowania, taktyka ${ }^{102}$. Widać wyraźnie ustalenie się nowoczesnej definicji, a nawet dominację konceptualizacji czasowej. To, jaką „metodą” i ,sztuką" była polityka, było ustalane na bieżąco w debacie publicznej, poprzez użycia pojęcia i robocze definicje tworzone przez pojęciowych innowatorów, takich jak ci omówieni w niniejszym artykule.

Narodowi demokraci w pewnym stopniu świadomie starali się ustalać zespół znaczeń pojęcia polityki na bliską sobie modłę. Zastanawiali się nad istotą polityki i kształtowali stosowane wobec podejmowanej działalności pojęcie. Dlatego też na tle innych ówczesnych obozów ideowych w największym chyba stopniu podjęli tematyzację polityki jako zjawiska ${ }^{103}$. Endeckie myślenie polityczne jest częścią szerszego zwrotu ku politycznemu realizmowi i nowożytnej koncepcji racji stanu. W tym sensie realizm polityczny endecji jest odpowiednikiem koncepcji niemieckich teoretyków Realpolitik ${ }^{104}$.

\footnotetext{
Por. M. Weber, Polityka jako zawód i powotanie, Warszawa 1989.

Dylemat dziejowy, s. 519.

100 Podobne znaczenie przypisywali polityce jeszcze w potowie XIX wieku niektórzy [...] uczeni.

101 Ilustrowana encyklopedia Trzaski, Everta i Michalskiego, t. 7, red. S. Lam, Warszawa 1930, s. 330.

102 Podręczny stownik jezzyka polskiego, Warszawa 1939, s. 231.

103 K. Palonen, Die Thematisierung der Politik als Phänomen: Interpretation der Geschichte des Begriffs Politik im Frankreich des 20. Jahrhunderts, Helsinki 1989.

104 Zob. tenże, Politik als Handlungsbegriff..., s. 31-40; V. Sellin, Politik. Na rozwój koncepcji endeckiej w kontekście nieskrywanych imperialnych interesów państw europejskich wskazuje K. Kawalec, Roman Dmowski. 1864-1939, Wrocław 2002, s. 56-57.
} 
W specyficznej sytuacji, w jakiej kształtowało się polskie słownictwo polityczne, ścieżka rozwojowa nie była jednak taka sama. W warunkach opracowania koncepcji działania politycznego poza państwem, a nawet wbrew państwu, nadrzędna rola państwa, jako instancji uzasadniającej działanie, musiała zostać zastąpiona przez naród ${ }^{105}$.

Działanie poza państwem w warunkach ograniczonej sprawczości nie spowodowało porzucenia pojęcia polityki i w konsekwencji ujmowania własnych poczynań jako niepolitycznych ${ }^{106}$. Wymusiło jednak taką konceptualizację polityki, w obrębie której działanie polityczne jest możliwe do realizacji. Nastąpiło ciekawe odwrócenie. Wedle przywołanego na początku spojrzenia na historię pojęć nowoczesny czas przejścia przynosi nasycenie pojęć politycznych i społecznych wymiarem normatywnym. Pojęcia takie zawierają horyzont czasowy, pewną strukturę antycypacji; przykładowo pojęcie rewolucji nie oznacza już obrotów ciał niebieskich, a nieodwracalną, często oczekiwaną, przyszłą zmianę społeczną ${ }^{107}$. Choć pojęcie polityki przeszło nieco inną drogę, to często rozwijając się w opozycji do absolutystycznego państwa, także poczęło zawierać utopijny naddatek umoralniającej krytyki ${ }^{108}$. W przypadku pism narodowodemokratycznych natomiast nabrało szybko realistycznego, adaptatywnego charakteru, związanego z mierzeniem się z okolicznościami i chwytaniem sposobności. Rosnąca przestrzeń doświadczenia (jak polityczna opresja imperialnych aparatów państwowych, klęski powstań) spowodowała wtórną redukcję horyzontu oczekiwań ${ }^{109}$. W tym sensie endeckie zmagania z pojęciem polityki łączą dwie czasowości - jedna niesie nowoczesne przejście w kierunku rozumienia polityki jako działania, druga typową dla dwudziestowiecznych debat korektę wobec nowoczesnego rozumienia pojęć, związaną z erozją prospektywnych oczekiwań wobec upływu czasu ${ }^{110}$.

105 Ciekawe jest porównanie polskiego pojęcia polityki z jego losami w języku rosyjskim. Tam było ono znacznie silniej związane z państwem, a nawet długo od niego nieoddzielne. Wynikało to nie tylko z powstawania nowoczesnego słownictwa politycznego w ścisłym związku z „własnym” państwem, ale też z działaniem bardziej dotkliwej cenzury, która blokowała rozpowszechnianie jakichkolwiek pojęć w znaczeniu mogącym podważyć praworządność władzy. Zob. W. Sperling, Vom Randbegriff zum Kampfbegriff. Semantiken des Politischen im ausgehenden Zarenreich (1850-1917), [w:] Politik. Situationen eines Wortgebrauchs im Europa der Neuzeit, red. W. Steinmetz, Frankfurt 2007. Dokładniejszych badań wymagałoby prześledzenie, jak zmiana kontekstu - czy to w obliczu galicyjskiego parlamentaryzmu, czy endeckiego poselstwa w Dumie - wpływała na pojęcie polityki w późniejszym okresie. W badanych tu tekstach nie uwidacznia się ujęcie polityki poprzez działalność parlamentarną.

106 Inaczej stało się np. wśród opozycji politycznej w państwach realnego socjalizmu, gdzie próbowano pomyśleć własną działalność właśnie poza polityką i przeciw niej. Zob. A. Arndt, Intellektuelle in der Opposition Diskurse zur Zivilgesellschaft in der Volksrepublik Polen, Frankfurt am Man 2007; D. Gawin, Wielki zwrot. Ewolucja lewicy i odrodzenie idei spoteczeństwa obywatelskiego 1956-1976, Kraków 2013.

R. Koselleck, Semantyka historyczna.

Tenże, Krytyka i kryzys, przeł. J. Duraj, M. Moskalewicz, Warszawa 2015.

Pierwotną propozycję teoretyczną można znaleźć w: tenże, Semantyka historyczna.

Problem adekwatności perspektywy historii pojęć do badań nad językiem politycznym XX w. jest przedmiotem ożywionych debat. Propozycje badania języków politycznych „wieku skrajności” można znaleźć w: Political Languages in the Age of Extremes, red. W. Steinmetz, London 2011. Szeroko dysku- 
Te asynchroniczne warstwy czasu w pojęciu polityki nałożyły się na konieczność konfrontacji z gwałtowną zmianą społeczną. Endecy byli świadomi dynamiki społecznej ich czasów i traktowali umasowienie polityki jako dany fakt, który można wykorzystać, ale którego nie można zakwestionować. Jasne było zatem, że ludność po raz pierwszy uczestnicząca w sferze publicznej nie ma gotowego repertuaru zachowań w nowej sytuacji. We wczesnym okresie endecy zdawali sobie sprawę, że nie można po prostu zignorować mobilizacji warstw ludowych i uparcie zaprzeczać jej wadze, bo wtedy szansę niesioną przez polityczną aktywizację mas wykorzysta ktoś inny ${ }^{111}$.

Teoretyczną odpowiedzią Narodowej Demokracji na tę sytuację była dynamiczna koncepcja podmiotu politycznego i podkreślenie roli samego uczestnictwa politycznego w jego kształtowaniu. Nie jest zatem tak, że polityka jest sferą wyrazu jakichś uprzednich preferencji czy żądań, nie jest też płaszczyzną konfliktu czy współpracy ukształtowanych już przedpolitycznie grup społecznych. Jest mierzącym się z okolicznościami, realistycznym działaniem, nieustannie odkształcanym przez okoliczności i prowadzonym w ciągłym odniesieniu do innych. Nie można więc prowadzić polityki samemu dla siebie, grać niejako w strachy z dziadem, co stanowi zabawkę niektórych naszych nieprzejednanych kierunków ${ }^{112}$. Same warunki brzegowe polityki są w zasadzie wyznaczane przez nowoczesność, niepodobna bowiem zapobiec demokratyzacji stosunków społecznych, która stanowi te warunki. Można i trzeba jednak dbać o to, by ów odbywający się proces polityzacji mas przebiegał w określonym i pożądanym kierunku. Podmioty polityczne są wytwarzane w samej praktyce działania politycznego. Lud nie jest kategorią empiryczną, jest on wytwarzany w procesie mobilizacji i artykulacji politycznej ${ }^{113}$.

Polityka w takim ujęciu jest pewnego rodzaju celowym działaniem wspólnym. Można je podejmować w różnych formach, a każde działanie wespół z innymi na rzecz narodowej sprawy jest zarazem przygotowaniem do dalszego zaangażowania. W różnych instytucjach, poprzez praktykę, lud miał nabywać kompetencji politycznych. Nie można z góry odmawiać mu udziału, a potem twierdzić, że nie ma doświadczenia politycznego. To nie tylko błędne koło elitarystycznego wykluczenia, ale i najkrótsza dro-

towaną propozycję rekonfiguracji relacji między przestrzenią doświadczenia a horyzontem oczekiwań jako istotną korektę do perspektywy Begriffsgeschichte dla badania pojęć w XX w. przedstawił C. Geulen, Plädoyer für eine Geschichte der Grundbegriffe des 20. Jahrhunderts, „Zeithistorische Forschungen/ Studies in Contemporary History” 2010, nr 7 . Na temat odkrycia i erozji przyszłości z punktu widzenia historii pojęć zob. L. Hölscher, Die Entdeckung der Zukunft, Frankfurt am Main 1999.

$111 \mathrm{Z}$ wielu tekstów rozważających ten problem zob. np. R. Dmowski, Kwestia robotnicza w programie demokratyczno-narodowym, „Przegląd Wszechpolski” 1903, nr 4.

112 Umiarkowanie w polityce, s. 220.

113 Nie ma tu niestety miejsca na analizę bardzo złożonych operacji, jakie dokonały się w dyskursie endeckim na pojęciu ludu, które było podstawowym referentem zakładanego przez endeków podmiotu politycznego w pierwszej fazie kształtowania się ich programu. Zob. T. Kulak, Jan Ludwik Poptawski. Biografia polityczna, Wrocław 1994; T. Wolsza, Narodowa Demokracja wobec chtopów w latach 1887-1914. Programy, polityka, dziatalność, Warszawa 1992; J. Żurawicka, Lud w ideologii „Gtosu” 1886-1894, „Kwartalnik Historyczny” 1956, t. 63, nr 4-5. Moje spojrzenie na narodowodemokratyczne zmagania z pojęciem ludu przedstawiam w W. Marzec, Rebelia i reakcja... 
ga do politycznej klęski w dobie umasowienia polityki ${ }^{114}$. Polityka nie była wówczas ograniczona do z góry określonej dziedziny, nie było też zawężane spectrum stanowisk, które mogły znaleźć wyraz w politycznym działaniu. Pojęcie polityki, jakim rozporządzali endecy wraz z przypisywaną dziedzinie politycznej autonomią (czy może anomią) i realizmem, pozostawało pojęciem otwartym, którego aktualnie istniejące polityczne konsekwencje zależały od relacyjnego układu innych pojęć, w którym pojęcie polityki było zagnieżdżone.

Horyzont myślenia politycznego uległ z czasem przekształceniu. W obliczu praktyki politycznej pojęcia, za pomocą których jest ona wyrażana i czyniona, zawsze ulegają zmianie. W tym przypadku kluczem do zrozumienia zmiany w pojęciu polityki jest ewolucja pojęcia narodu, głównego zwornika endeckiego dyskursu politycznego. Zarówno działanie polityczne, jak i myśl polityczna, dyskurs skierowany do in spe członków tego narodu, powoływać miały naród do życia. Pośrednio dowodziło to też wagi przykładanej do myśli społecznej czy polemiki ideowej. Myśl społeczna nie tylko urabia instynkty narodu, ale też tworzy jego ciało, przelewa weń swą energię, rządzi nim i wciela się przez to $\mathrm{w}$ formy jego bytu ${ }^{115}$. W tym akurat aspekcie zarówno Balicki, jak i cała formacja endecka nie pomylili się. Skutki tego zaś są odczuwalne do dzisiaj.

Konfiguracja pojęć stanowiąca zręby narodowodemokratycznego myślenia była narażona na coraz gwałtowniejsze zmiany w dobie gwałtownych przekształceń społecznych. Politykę trzeba było prowadzić zupełnie inaczej u progu rewolucji 1905 r. Kiedy spoteczeństwu naszemu zaświecita nadzieja lepszego jutra - nastąpit ów zwrot ku polityce, który stanowi tak wybitny rys obecnej doby ${ }^{116}$. Konstatując „zwrot ku polityce”, endecy przyznawali, że apolityczność „mas” była czymś szkodliwym i niemożliwym do utrzymania. $Z$ drugiej strony empiryczne zdarzenia nie szły po ich myśli, co budziło niechęć do takiego obrotu spraw. Ta wtaśnie, czysto zewnętrzna geneza obecnego ruchu politycznego w kraju sprawia, że ogót jest do niego niedostatecznie przygotowany ${ }^{117}$. Jak pamiętamy, działanie prawdziwie polityczne musi być też narodowe, a jeśli nie jest, to musi być pochodzącą z zewnątrz aberracją. Ruch polityczny, który endecy zaakceptowaliby bez zastrzeżeń, musiałby być efektem długotrwałej pracy uświadamiającej lud na sposób narodowy, tak by wystąpił on pod jednym sztandarem i mógł być kontrolowany przez przywódców Narodowej Demokracji. Tymczasem sytuacja wyglądała zupełnie inaczej $^{118}$.

Naród posłużył do uzasadnienia kierunku działań, w momencie gdy wcześniejsze wizje były natychmiast dostosowywane do odmiennej od oczekiwań politycznej praktyki. Pojęcie narodu zostało zabsolutyzowane i wyniesione na piedestał jako oś całego endeckiego myślenia, a także gwarant i uzasadnienie praktyki politycznej w dobie znik-

114 J.L. Popławski, Pisma polityczne, s. 31.

115 Etyka ipolityka, [w:] Z. Balicki, Parlamentaryzm..., s. 531.

116 Podstawy polityki polskiej, [w:] R. Dmowski, Myśli nowoczesnego Polaka, s. 86.

117 Tamże.

118 Specyficzne oburzenie na sukcesy agitacyjne socjalistów przedstawia np. S. Kozicki, Historia Ligi Narodowej..., s. 262. 
nięcia innej transcendentnej poręki ${ }^{119}$. W rezultacie labilne i otwarte pojęcie polityki zostało ustabilizowane, a jego praktyczne reperkusje określone. Nie były to jednak konsekwencje demokratyczne i pluralistyczne, które pozostały wciąż potencjalnie zawarte w czasowej konceptualizacji polityki, charakterystycznej dla wielu form nowoczesnego myślenia politycznego i nieobcej - jak widzieliśmy - endecji. W obliczu wydarzeń, takich jak narastająca demokratyzacja życia politycznego (widoczna zarówno na ulicach, jak i w obszarze politycznych wyobrażeń), nastąpiła reorientacja pojęcia polityki, ponowna dominacja konceptualizacji przestrzennej. Wyznaczała ona granice "polityczności", zarówno oddzielając program narodowy od reszty niepolitycznych i bezcelowych zabiegów, jak i określając, kto powołany jest do działań politycznych, a kto winien pozostać tylko biernym i karnym podwładnym. To ona umożliwiała relegowanie politycznych oponentów poza obszar polityki poprzez opisany wyżej ruch depolityzacji, jak i elitarny zwrot w myśleniu i działaniach Narodowej Demokracji ${ }^{120}$.

Gdy za jedyną prawdziwą politykę uznali politykę narodową, a za jedynych wyrazicieli interesu narodowego siebie samych, narodowi demokraci utwierdzili się w antypluralistycznej, antydemokratycznej i elitarystycznej wizji polityki. Efekty zmiany pojęciowej dały o sobie znać w politycznym myśleniu i dyskursie endecji po rewolucji 1905 r., gdy integralny nacjonalizm, często budujący swoją legitymizację na antysemityzmie, i autorytarna wizja dyscypliny zaczęły dominować, przenikając też do wewnętrznej struktury organizacji ${ }^{121}$. Obecny w myśli politycznej Narodowej Demokracji polityczny realizm, nowoczesna konceptualizacja temporalna, otwarta wizja polityki jako działania niezdeterminowanego i konfrontacja z momentem politycznym ${ }^{122}$ same w sobie nie zapewniają demokratycznego, postępowego oblicza polityki. Taka wizja polityki obarczona jest tym, co Simon Critchley nazwał deficytem moralnym ${ }^{123}$. Nie

119 W. Marzec, Ponowne obsadzenie... Na temat rosnącego znaczenia organicystycznej, biologistycznej wizji narodu zob. T. Kizwalter, O nowoczesności narodu...; tenże, Nowoczesny Polak, Darwin i Nietzsche, „Przegląd Polityczny” 2002, nr 56; G. Krzywiec, Szowinizm po polsku...; R. Zimand, Uwagi o teorii narodu...

120 Przechodzenie endecji na pozycje konserwatywne i zmiany jej bazy społecznej omawiają pod różnymi kątami: B. Grott, Zygmunt Balicki. Ideolog Narodowej Demokracji, Kraków 1995, s. 3; M. Jaskólski, Konserwatyzm-nacjonalizm. Studia nad konfrontacjami ideowymi konserwatyzmu krakowskiego i demokracji narodowej przed 1914 r., Kraków 1989; Y.S. Kanfer, Eódź. Industry, Religion, and Nationalism in Russian Poland, 1880-1914, Ph.D. dissertation, Yale University, 2011, s. 248-257; S. Kozicki, Historia Ligi Narodowej..., s. 284-285; R. Wapiński, Roman Dmowski, s. 157.

121 W sprawie rozwoju politycznego antysemityzmu endecji zob. R. Blobaum, The Politics of Antisemitism...; W. Marzec, What Bears Witness of the Failed Revolution?...; A. Walicki, The Troubling Legacy...; T.R. Weeks, From Assimilation to Antisemitism. The "Jewish Question” in Poland, 1850-1914, DeKalb 2006. Na temat hierarchii wewnętrznej M. Jaskólski pisze: otwarte gtoszenie antyindywidualizmu $w$ ideologii, programach partii przybierato charakter hasta propagandowego. W praktyce zaś prowadzito do rozrostu więzi wewnatrzpartyjnej, wzmożonej dyscypliny, swoistej uniformizacji i totalizacji życia cztonków i zatożonego niemal z góry elitaryzmu wewnątrzpartyjnego. M. Jaskólski, Konserwatyzm-nacjonalizm..., s. 29.

122 O. Marchart, Post-Foundational Political Thought. Political Difference in Nancy, Lefort, Badiou and Laclau, Edinburgh 2007.

123 S. Critchley, Czy teoria hegemonii obarczona jest deficytem moralnym?, „Hybris” 2012, nr 16. 
ma ona określonego wektora, może być podstawą adekwatnej do wyzwań praktyki demokratycznej, ale też może wyrodzić się w podporządkowaną arbitralnym celom narodowym praktykę autorytarną. Zmiana w obrębie endeckiej konceptualizacji polityki pomaga wyjaśnić transformację myślenia i praktyki obozu narodowego ${ }^{124}$. Jest też ważnym elementem procesu kształtowania się nowoczesnego słownictwa politycznego i polskiej sfery publicznej w takim, a nie innym kształcie.

Artykuł ten powstał w ramach projektu finansowanego ze środków Narodowego Centrum Nauki, umowa nr UMO-2012/05/N/HS3/01158, realizowanego w Katedrze Socjologii Kultury Uniwersytetu Łódzkiego. Dziękuję Rafałowi Zawiszy, Grzegorzowi Markiewiczowi, Andrzejowi M. Kaniowskiemu oraz Markowi Czyżewskiemu i pozostałym uczestnikom seminarium Zakładu Badań Komunikacji Społecznej na Uniwersytecie Łódzkim za lekturę i krytyczne uwagi.

\section{BIBLIOGRAFIA}

Andersen N.Å., Discursive Analytical Strategies. Understanding Foucault, Koselleck, Laclau, Lubmann, Bristol 2003.

Antisemitism and Its Opponents in Modern Poland, red. R. Blobaum, Ithaca 2005.

Arndt A., Intellektuelle in der Opposition. Diskurse zur Zivilgesellschaft in der Volksrepublik Polen, Frankfurt am Main 2007.

Arystoteles, Polityka, Warszawa 2004.

Balicki Z., Parlamentaryzm. Wybór pism, Kraków 2008.

Balicki Z., Z doby przetomu myśli narodowej, Moskwa 1916.

Blobaum R., Rewolucja. Russian Poland, 1904-1907, Ithaca 1995.

Blobaum R., The Politics of Antisemitism in Fin-de-Siècle Warsaw, „The Journal of Modern History" 2001, Vol. 73, nr 2.

Bończa-Tomaszewski N., Demokratyczna geneza nacjonalizmu. Intelektualne korzenie ruchu narodowo-demokratycznego, Warszawa 2001.

Critchley S., Czy teoria hegemonii obarczona jest deficytem moralnym?, „Hybris” 2012, nr 16.

Cywiński B., Rodowody niepokornych, Warszawa 2010.

Dawidowicz A., Zygmunt Balicki (1858-1916). Dziatacz i teoretyk polskiego nacjonalizmu, Kraków 2006.

Dmowski R., Myśli nowoczesnego Polaka, Wrocław 2002.

Dmowski R., Pisma, t. 3: Dziesięć lat walki, Częstochowa 1938.

Freeden M., Ideologies and Political Theory. A Conceptual Approach, Oxford-New York 1998.

124 Na temat tej zmiany zob. N. Bończa-Tomaszewski, Demokratyczna geneza nacjonalizmu... Zwrot ku dyscyplinie został opisany w: G. Krzywiec, Szowinizm po polsku..., s. 313-315; B. Porter, Democracy and Discipline in Late Nineteenth Century Poland, „The Journal of Modern History” 1999, Vol. 71, nr 2. 
Freeden M., Ideology and Conceptual History, [w:] Political Concepts and Time. New Approaches to Conceptual History, red. J. F. Sebastián, Santander 2011.

Freeden M., The Political Theory of Political Thinking. The Anatomy of a Practice, Oxford 2013.

Gawin D., Wielki zwrot. Ewolucja lewicy i odrodzenie idei spoteczeństwa obywatelskiego 1956-1976, Kraków 2013.

Geulen C., Plädoyer für eine Geschichte der Grundbegriffe des 20. Jahrbunderts, „Zeithistorische Forschungen/Studies in Contemporary History" 2010, nr 7.

Grott B., Zygmunt Balicki. Ideolog Narodowej Demokracji, Kraków 1995.

Handbuch politisch-sozialer Grundbegriffe in Frankreich 1680-1820, red. R. Reinchardt, München 1985.

Hölscher L., Die Entdeckung der Zukunft, Frankfurt am Main 1999.

Ifversen J., About Key Concepts and How to Study Them, „Contributions to the History of Concepts" 2011, Vol. 6, nr 1.

Janowski M., Polska myśl liberalna do 1918 roku, Kraków-Warszawa 1998.

Jaskólski M., Konserwatyzm-nacjonalizm. Studia nad konfrontacjami ideowymi konserwatyzmu krakowskiego i demokracji narodowej przed 1914 r., Kraków 1989.

Jaszczuk A., Spór pozytywistów z konserwatystami o przysztość Polski 1870-1903, Warszawa 1986.

Jordheim H., Against Periodization: Koselleck's Theory of Multiple Temporalities, „History and Theory" 2012, nr 51.

Kalembka S., Wielka emigracja 1831-1863, Toruń 2003.

Kanfer Y.S., Eódź. Industry, Religion, and Nationalism in Russian Poland, 1880-1914, Ph.D. dissertation, Yale University, 2011.

Kawalec K., Roman Dmowski. 1864-1939, Wrocław 2002.

Kimla P., Historycy-politycy jako źródto realizmu politycznego. Tukidydes - Polibiusz - Machiavelli, Kraków 2009.

Kizwalter T., „Nowatorstwo i rutyny”: spoteczeństwo Królestwa Polskiego wobec procesów modernizacji, 1840-1863, Warszawa 1991.

Kizwalter T., Nowoczesny Polak, Darwin i Nietzsche, „Przegląd Polityczny” 2002, nr 56.

Kizwalter T., O nowoczesności narodu: przypadek Polski, Warszawa 1999.

Koselleck R., Einleitung, [w:] Geschichtliche Grundbegriffe, t. 1, Stuttgart 1972.

Koselleck R., Krytyka i kryzys, przeł. J. Duraj, M. Moskalewicz, Warszawa 2015.

Koselleck R., Semantyka historyczna, przeł. W. Kunicki, Poznań 2012.

Koselleck R., Warstwy czasu. Studia z metahistorii, przeł. K. Krzemieniowa, J. Merecki, Warszawa 2012.

Koselleck R., Zur historisch-politischen Semantik asymmetrischer Gegenbegriffe, [w:] Vergangene Zukunft, Frankfurt am Main 1979.

Kozicki S., Historia Ligi Narodowej. (Okres 1887-1907), Londyn 1964.

Kryński A., Niedźwiedzki W., Stownik jezzyka polskiego, Warszawa 1901.

Krzywiec G., Szowinizm po polsku. Przypadek Romana Dmowskiego (1886-1905), Warszawa 2009.

Kulak T., Jan Ludwik Poptawski. Biografia polityczna, Wrocław 1994.

Kułakowski M., Roman Dmowski w świetle listów i wspomnień, Londyn 1968. 
Kurczewska J., Naród w socjologii i ideologii polskiej. Analiza porównawcza wybranych koncepcji z przetomu XIX i XX wieku, Warszawa 1979.

Ilustrowana encyklopedia Trzaski, Everta i Michalskiego, t. 7, red. S. Lam, Warszawa 1930.

Linde S.B., Stownik jezzyka polskiego, Lwów 1858.

Machiavelli N., Książę. Rozważania nad pierwszym dziesięcioksiegiem historii Rzymu Liwiusza, Warszawa 2008.

Marchart O., Post-Foundational Political Thought. Political Difference in Nancy, Lefort, Badiou and Laclau, Edinburgh 2007.

Markiewicz G., Między państwem obcym a idea państwa wtasnego. Świadomość państwowa polskich elit intelektualnych w latach 1864-1914, Łódź 2010.

Marzec W., Ponowne obsadzenie pustego miejsca - endecki naród i polityczna nowoczesność, „Hybris" 2014, nr 24.

Marzec W., Rebelia i reakcja. Rewolucja 1905 roku i plebejskie doświadczeniepolityczne, KrakówŁódź 2016.

Marzec W., What Bears Witness of the Failed Revolution? The Rise of Political Antisemitism during the 1905-1907 Revolution in the Kingdom of Poland, „Eastern European Politics and Societies" 2016, Vol. 30, nr 1.

Mencwel A., Etos lewicy. Esej o narodzinach kulturalizmu polskiego, Warszawa 2009.

Micewski A., Roman Dmowski, Warszawa 1971.

Olsen N., History in the Plural. An Introduction to the Work of Reinhart Koselleck, New York 2012.

Opaliński E., Kultura polityczna szlachty polskiej w latach 1587-1652. System parlamentarny a spoteczeństwo obywatelskie, Warszawa 1995.

Palonen K., Die Thematisierung der Politik als Phänomen: Interpretation der Geschichte des Begriffs Politik im Frankreich des 20. Jahrhunderts, Helsinki 1989.

Palonen K., Max Weber als Begriffspolitiker, „Etica \& Politica/Ethics \& Politics” 2005, nr 2.

Palonen K., Politik als Handlungsbegriff. Horizontwandel d. Politikbegriffs in Deutschland 1890-1933, Helsinki 1985.

Palonen K., The Struggle with Time. A Conceptual History of „Politics” as an Activity, Hamburg 2006.

Pepłowski F., Stownictwo i frazeologia polskiej publicystyki okresu oświecenia i romantyzmu, Warszawa 1961.

Pitkin H.F., Fortune Is a Woman. Gender and Politics in the Thought of Niccolo Machiavelli. With a New Afterword, Chicago 1999.

Pocock J.G.A., The Machiavellian Moment Florentine Political Thought and the Atlantic Republican Tradition, Princeton 2003.

Podręczny stownik jezyka polskiego, Warszawa 1939.

Political Languages in the Age of Extremes, red. E. Steinmetz, London 2011.

Popławski J.L., Pisma polityczne, Warszawa 1910.

Porter B., Democracy and Discipline in Late Nineteenth Century Poland, „The Journal of Modern History" 1999, Vol. 71, nr 2.

Porter B., Gdy nacjonalizm zacząt nienawidzić: wyobrażenia nowoczesnej polityki $w$ dziewiętnastowiecznej Polsce, przeł. A. Nowakowska, Sejny 2011.

Porter B., Who Is a Pole and Where Is Poland? Territory and Nation in the Rhetoric of Polish National Democracy before 1905, „Slavic Review” 1992, Vol. 51, nr 4. 
Praktyczny stownik wspótczesnej polszczyzny, red. H. Zgółkowa, Poznań 1994.

Puszkow-Bańka A., Polska i Polacy w myśli narodowej demokracji na przetomie XIX i XX wieku (Jan Ludwik Poptawski, Zygmunt Balicki, Roman Dmowski), Kraków 2013.

Rzegocki A., Racja stanu a polska tradycja myślenia o polityce, Kraków 2008.

Rewolucja 1905. Przewodnik, red. W. Marzec, K. Piskała, Warszawa 2013.

Sellin V., Politik, [w:] Geschichtliche Grundbegriffe, t. 4, Stuttgart 1974.

Semantiken des Politischen. Vom Mittelalter bis ins 20. Jahrhundert, red. U. Meier, W. Steinmetz, M. Pappenheim, Göttingen 2012.

Skinner Q., Machiavelli, Oxford-New York 1981.

Sperling W., Vom Randbegriff zum Kampfbegriff. Semantiken des Politischen im ausgehenden Zarenreich (1850-1917), [w:] Politik. Situationen eines Wortgebrauchs im Europa der Neuzeit, red. W. Steinmetz, Frankfurt 2007.

Spoteczeństwo i polityka. Dorastanie do demokracji: kultura polityczna w Królestwie Polskim na poczatku XX wieku, red. A. Żarnowska, S. Wolsza, Warszawa 1993.

Tazbir J., Kultura szlachecka w Polsce. Rozkwit, upadek, relikty, Warszawa 1978.

Toruńczyk B., Narodowa Demokracja. Antologia myśli politycznej „Przeglądu Wszechpolskiego” 1895-1905, Londyn 1983.

Trenscnyi B., Conceptual History and Political Languages. On the Central-European Adaptation of the Contextualist-Conceptualist Methodologies of Intellectual History, [w:] Prague Perspectives. Studies in Central and Eastern Europe, red. P. Roubal, V. Veber, Prague 2004.

Ury S., Barricades and Banners. The Revolution of 1905 and the Transformation of Warsaw Jewry, Stanford 2012.

Walicki A., Idea narodu w polskiej myśli oświeceniowej, Warszawa 2000.

Walicki A., The Troubling Legacy of Roman Dmowski, „Dialogue and Universalism” 2011, nr 4. Wapiński R., Narodowa Demokracja 1893-1939. Ze studiów nad dziejami myśli nacjonalistycznej, Wrocław 1980.

Wapiński R., Problem państwa w koncepcjach politycznych obozu narodowego, [w:] Państwo w polskiej myśli politycznej, Wrocław 1988, Polska Myśl Polityczna XIX i XX Wieku, nr 7.

Wapiński R., Roman Dmowski, Lublin 1989.

Weber M., Polityka jako zawód i powotanie, Warszawa 1989.

Weeks T.R., Fanning the Flames. Jews in the Warsaw Press, 1905-1912, „East European Jewish Affairs" 1998, Vol. 28, nr 2.

Weeks T.R., From Assimilation to Antisemitism. The "Jewish Question" in Poland, 1850-1914, DeKalb 2006.

Widzicka M., Semantyka historyczna w ujęciu Reinharta Kosellecka. Zarys problematyki, „Historyka" 2010, t. 40, nr 10.

Wolin S. S., Politics and Vision: Continuity and Innovation in Western Political Thought, Princeton 2004.

Wolsza T., Narodowa Demokracja wobec chtopów w latach 1887-1914. Programy, polityka, dziatalność, Warszawa 1992.

Zimand R., Uwagi o teorii narodu na marginesie analizy nacjonalistycznej teorii narodu, „Studia filozoficzne" 1967, nr 4 (51).

Żurawicka J., Lud w ideologii „Gtosu” 1886-1894, „Kwartalnik Historyczny” 1956, t. 63, nr 4-5. 
Mgr Wiktor MARZEC - ukończył studia socjologiczne i filozoficzne na Uniwersytecie Łódzkim. Interesuje się socjologią historyczną, teorią dyskursu, historią robotniczą, historią pojęć i filozofią polityczną. Obecnie przygotowuje rozprawę doktorską na Wydziale Socjologii i Antropologii Społecznej Uniwersytetu Środkowoeuropejskiego w Budapeszcie (CEU) poświęconą relacji robotników do polityki w Królestwie Polskim na przełomie XIX i XX w. Stypendia naukowe odbywał m.in. na Uniwersytecie Michigan i na Uniwersytecie Humboldta w Berlinie. Redaktor działu krytyczne nauki społeczne w czasopiśmie „Praktyka Teoretyczna”. Publikował m.in. w „Thesis Eleven”, "Journal of Historical Sociology” oraz „Eastern European Politics and Societies”. 